Article

\title{
Geomorphological Dating of Pleistocene Conglomerates in Central Slovenia Based on Spatial Analyses of Dolines Using LiDAR and Ground Penetrating Radar
}

\author{
Teja Čeru ${ }^{1, *}$ (D) , Ela Šegina ${ }^{2}$ and Andrej Gosar ${ }^{1,3}$ \\ 1 Faculty of Natural Sciences and Engineering, University of Ljubljana, Aškerčeva 12, \\ 1000 Ljubljana, Slovenia; andrej.gosar@gov.si \\ 2 Independent Researcher, Miklošičeva 4a, 1230 Domžale, Slovenia; ela.segina@gmail.com \\ 3 Slovenian Environment Agency, Seismology and Geology Office, Vojkova 1b, \\ 1000 Ljubljana, Slovenia \\ * Correspondence: teja.ceru@ntf.uni-lj.si; Tel.: +386-40-752-084
}

Received: 23 October 2017; Accepted: 17 November 2017; Published: 24 November 2017

\begin{abstract}
On Kranjsko polje in central Slovenia, carbonate conglomerates have been dated to several Pleistocene glacial phases by relative dating based on the morphostratigrafic mapping and borehole data, and by paleomagnetic and ${ }^{10} \mathrm{Be}$ analyses. To define how the age of conglomerates determines the geomorphological characteristics of karst surface features, morphometrical and distributive spatial analyses of dolines were performed on three test sites including old, middle, and young Pleistocene conglomerates. As dolines on conglomerates are covered by a thick soil cover and show a strong human influence, the ground penetrating radar (GPR) method was first applied to select dolines appropriate for further morphometrical and distributive analyses. A considerable modification of natural morphology was revealed for cultivated dolines, excluding this type of depression from spatial analyses. Input parameters for spatial analyses (doline rim and deepest point) were manually extracted from the $1 \times 1 \mathrm{~m}$ grid digital elevation model (DEM) originating from the high-resolution LiDAR (Light Detection and Ranging) data. Basic geomorphological characteristics, namely circularity index, planar size, depth, and density index of dolines were calculated for each relative age of conglomerates, and common characteristics were determined from these data to establish a general surface typology for a particular conglomerate. The obtained surface typologies were spatially extrapolated to the wider conglomerate area in central Slovenia to test the existent geological dating. Spatial analyses generally confirmed previous dating, while in four areas the geomorphological characteristics of dolines did not correspond to the existing dating and require further revision and modification. Doline populations exhibit specific and common morphometrical and distributive characteristics on conglomerates of a particular age and can be a reliable and fast indicator for their dating.
\end{abstract}

Keywords: doline; karst; land cultivation; morphometrical analysis; distributive analysis; conglomerate; LiDAR; digital elevation model (DEM); ground penetrating radar (GPR); Kranjsko polje

\section{Introduction}

Consolidated and unconsolidated clastic deposits in the Ljubljana basin (central Slovenia) have been related to Quaternary alternation of glacial and interglacial periods by several relative and absolute dating methods. The specific morphological characteristics of a surface linked to these different ages of deposits have already been noticed and briefly described by several authors [1-3]. Šifrer [1] had noticed that conglomerates are karstified to different degrees depending on their age. 
He observed that dolines lost their typical forms and are elongated and shallower on the old Günz conglomerate compared to Mindel conglomerate, where dolines are circular and deep [1]. He also noticed that the youngest Riss conglomerate is almost unaffected by karstification and that the surface is only slightly undulating.

The linkage between the morphometrical properties of doline populations and a particular age of carbonate conglomerate terraces was noticed for late-Miocene conglomerate in Italy [4]. However, the morphometrical and distributive characteristics of a particular relative age of a conglomerate have not been quantitatively observed and typified yet. Karst surface morphology, in particular doline population properties, also has not been applied as a quantified tool to date carbonate conglomerate terraces.

New methodologies for capturing relief data are more available nowadays and offer new extensions to modern spatial analyses. The increasingly available high-resolution LiDAR (Light Detection and Ranging) method for obtaining elevation data and creating digital elevation models (DEMs) is still in early stages of ability and reliability testing compared to traditional topographic and aerial surveying methods in modern karst geomorphology [5]. Researches applying high-resolution DEMs are mainly focused on automation of dolines detection and delineation [5-8], rather than on interpretations of the acquired geomorphological data [4,9].

In order to extract relevant spatial information from high resolution input data, a careful selection of reliable test samples is required. Dolines have traditionally been subject to intensive anthropogenic reshaping, thus the human impact should be taken into consideration when selecting dolines for further spatial analyses. People have used dolines for agricultural land purposes and have transformed them in order to gain the surface suitable for cultivation [10]. Nowadays, many dolines are no longer used for traditional activities, such as farming, gardening, pasturing, and water supply. They are abandoned or completely filled with various kinds of unknown material [11]. The morphological difference between uncultivated and cultivated dolines can be indicated already from a visual examination of high-resolution digital elevation models (DEMs). Cultivated dolines in the study area seem to be shallower and leveled compared to those that were uncultivated. As the quality of morphometrical and distributive analyses essentially depends on the relevance of the input data, ground penetrating radar (GPR) was employed to define the representative doline sample.

Dolines and their morphometrical and distributive properties have been mostly studied on compact carbonate rocks (limestones, dolomites). Ferrarese and Sauro [4] studied the conglomerate karst of Montello in Italy, which they denote as "the classical karst of the conglomerate rock" because of the similarities to the classical karst on limestones in Slovenia (Kras). Due to the particularity of karstification in carbonate conglomerates $[4,12]$ the results of this study could not be directly transmitted to karst surfaces on carbonate rocks such as limestones and dolomites.

Spatial relief characteristics were quantified using high-resolution LiDAR data, and the typification of karst surfaces on conglomerates of different relative ages was generated. Types of karst surfaces were specified by morphometrical and distributive characteristics of dolines. They served as a tool for dating wider conglomerate terraces in the area.

\section{Geological Settings of Study Area and the Age of Quaternary Deposits}

The Ljubljana basin was formed along the Sava fault and filled with glacial, glaciofluvial, and fluvial sediments deposited in glacial periods in Quaternary [1,2]. Quaternary deposits overlie impermeable, poorly lithified Oligocene mudstone ("sivica"), which covers underlying Tertiary limestones (Figure 1). Pebbles that constitute the conglomerates are mostly carbonate, and the cement mostly consists of calcite $[2,13,14]$. The non-carbonate parts (around 10\%) are quartz pebbles [13] and pebbles of mainly sedimentary rocks [3]. Uneven surfaces of the cave walls, where the pebbles protrude out, show that the carbonate cement dissolves faster than pebbles in conglomerate [12].

Karst and contact-karst surface features such as dolines, shafts, blind and pocket valleys have developed in conglomerates of the wider area. Several small caves have been found in conglomerates 
of all ages. Four general types of eogenetic caves were recognized on the older conglomerate terrace Udin Boršt: linear stream caves, shelter caves, breakdown caves, and vadose shafts [15,16]. Most of them are narrow horizontal passages that developed at the contact between the permeable carbonate conglomerates and the impermeable Oligocene mudstone "sivica" [12].

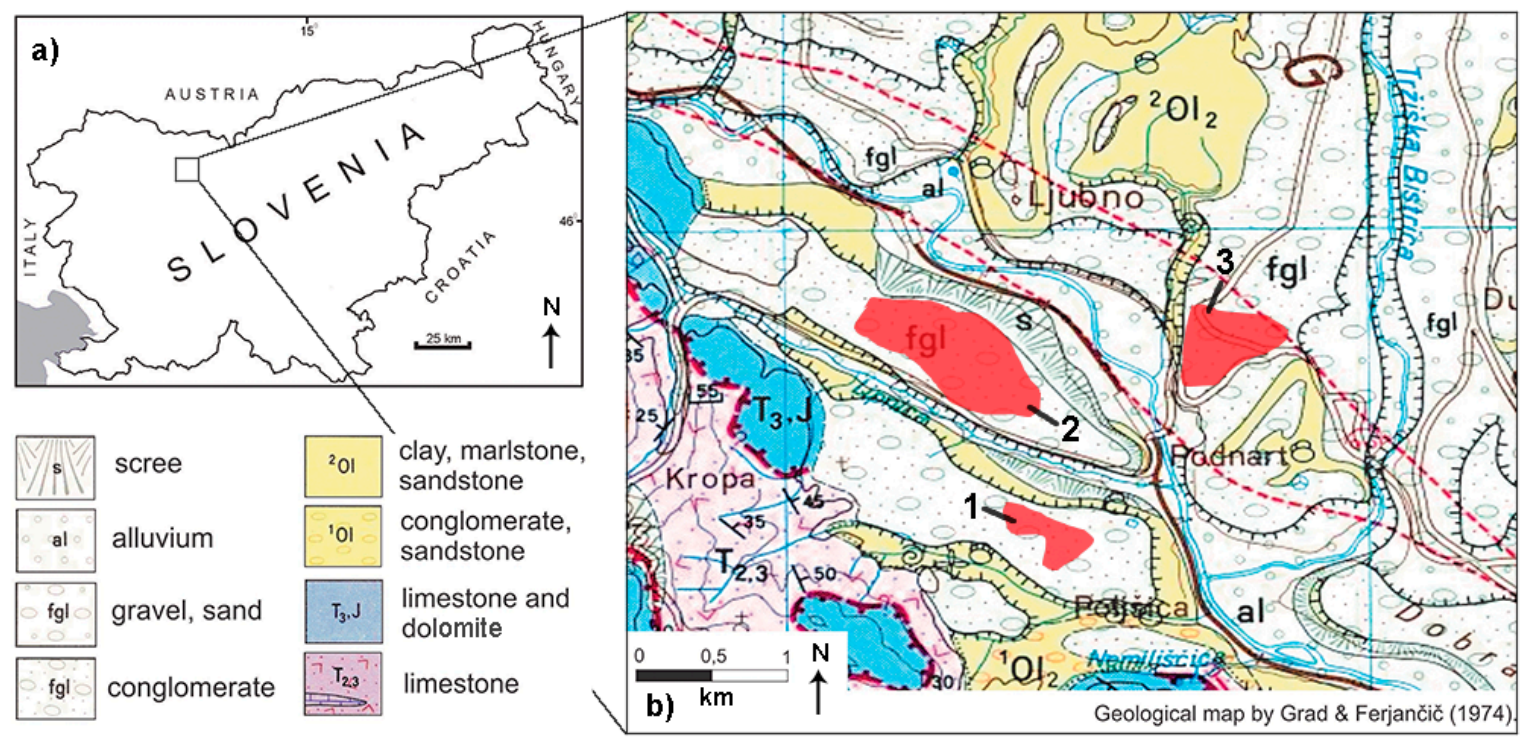

Figure 1. (a) The location of the study area; (b) A geological map [17] of the study area with three test sites (1: Poljšica; 2: Dobrava; 3: Podbrezje).

The first relative dating techniques were based on the comparison of the relative elevation of the surfaces, the induration of conglomerates (the degree of the hardening and cementation), as well as the degree of surface degradation in terms of erosion, karstification, and soil thickness $[1,2,18,19]$. Four major morphostratigraphic units were distinguished in the Ljubljana Basin (Table 1): the Older conglomerate fill of Günz age, the Middle conglomerate fill of Mindel age, the Younger conglomerate fill of Riss age, and Gravel fill of Würm age [1,2,19,20]. Würm gravel fill is related to the latest maximum cold period, based on the palynological analysis of a lacustrine sediments core [21].

Absolute age estimations of conglomerates were done by cosmogenic-nuclide burial dating using ${ }^{10} \mathrm{Be}$ (cosmogenic radionuclides dating) and paleomagnetic methods [22-24]. Absolute dating (cosmogenic-nuclide burial dating using ${ }^{26} \mathrm{Al}$ and ${ }^{10} \mathrm{Be}$ ) gave a burial age of $1.86 \pm 0.19 \mathrm{Ma}$ for the oldest conglomerate terrace Udin Boršt [25]. The chronological and relative ages of gravel and conglomerate fills are quite well accepted, starting from Penck and Brückner [26], while absolute dating is still ambiguous.

All three conglomerates are covered with a thick soil layer. The thickness of soil varies from $1 \mathrm{~m}$ to more than $8 \mathrm{~m}$, depending on the age of the conglomerate. However, soil thickness differs between areas of each individual conglomerate fill due to multiple periods of gravel deposition, or due to the initial differences of the deposits [27]. Soil classification range from Mollisols on the youngest Würm conglomerate, to Alfisols on the Riss, and Ultisols on the Mindel and Günz [22,27]. Soil thickness, the thickness of Bt horizons, the amount and continuity of clay coatings, and the amount of Fe and Mn concretions increase with soil age [27]. The variability of soil properties is generally higher within subareas than between areas of the individual conglomerate fill, except for soil thickness.

Study sites of three different conglomerates, named young, middle, and old in this study, correspond to the Younger, Middle, and Older conglomerate infills named by Žlebnik. Visual analyses of the Ljubljana basin conglomerate areas indicated a high uniformity of doline properties on particular ages of conglomerates. Locations of study sites (Podbrezje, Dobrava, Poljšica) were selected on the basis of geological maps done by Žlebnik [2] and Pavich and Vidic [22] on locations with accordant 
dating of both studies that are located close together for easier visual representation on the map. The borders of study sites were defined so as to include only forested dolines.

Table 1. The relative and absolute dating methods and inferred ages for the three study sites. The names of glaciations are used as morphostratigraphic and not chronostratigraphic terms.

\begin{tabular}{ccccc}
\hline & Locations of Test Sites & Relative Dating [2] & \multicolumn{2}{c}{ Absolute Dating [22,24] } \\
\cline { 3 - 5 } & & Related Glaciations & Estimated Age (ka) & Uncertainty Intervals (ka) \\
\hline Gravel & $/$ & Würm & Würm I, II, III (62, 44, 32) & $(50-70,40-50,20-35)$ \\
Young conglomerate & Podbrezje & Riss & Riss, 450 & $435-515$ \\
Middle conglomerate & Dobrava & Mindel & Mindel I, II (960, 980) & $(780-1000,>780)$ \\
Old conglomerate & Poljšica & Günz & Günz 1800 & $>1000$ \\
\hline
\end{tabular}

\section{Methods}

\subsection{LiDAR and Morphometrical Analyses}

New methods for automated doline detection and delineation as well as numerous tests of their reliability are lately subject to considerable expansion [5,7,8,28,29]. Additionally, more and more precise input data (LiDAR) for such researches has recently been made available, but issues such as understanding the concept of surface karstification and the pitfalls of new methods should be considered when trying to obtain results of the same quality as those expected from high-resolution data.

Šušteršič [30] developed The Pure Karst Model with which he recognized the fundamental processes of karstification having a vertical direction of outflow and resulting in basic elements of karst surface, which are centrically organized depressions and intermediate elevations. The configuration of such a surface does not follow the principles of fluvial morphology that are based on surface runoff and result in a connected drainage system consisting of valleys and intermediate ridges. This should be considered at data interpolation (some methods favor the hydrologically correct DEMs creating a connected drainage structure-for example the interpolation tool "Topo to raster" by ArcGIS) and when detecting and delineating karst depressions (some methods detect hydrologically closed depressions that are based on surface runoff). Due to high spatial heterogeneity of rock properties and vertical drainage, the karst surface is vertically irregular and therefore depressions often do not have a hydrologically closed upper rim. Such characteristics of the karst surface prevent researchers from employing tools for automated doline detection and delineation that are based on fluvial laws of surface runoff. Obu and Podobnikar [29] presented the low precision of the automated recognition of karst depressions obtained from DEMs (Digital Elevation Models). They employed a $12.5 \mathrm{~m}$ resolution DEM, but did not even detect depressions with a $40 \mathrm{~m}$ diameter. Following some recommendations, the point density of LiDAR data required for the detection and delineation of dolines is established to be at least $5-12 \mathrm{pt} / \mathrm{m}^{2}$ [31].

The importance and the problem of the doline upper rim definition have already been discussed by several authors [32-34]. Despite this, in most studies the doline upper rim is simply treated as the uppermost closed contour [5,35]. Even though it is the most reasonable definition of the doline perimeter, the principle of "an abrupt change in the surface slope" [33] has seldom been used in practice due to its fieldwork requirements. Newly available high-resolution LiDAR data allows manual delineation of dolines using the same method with a less time-consuming procedure.

In this research, the criteria for detecting a doline was "a depression of any size and depth recognizable on the $1 \times 1 \mathrm{~m}$ grid DEM". Doline rims were, with some prior field examination, determined visually and digitized manually from the shaded relief with the principle of "an abrupt change in the surface slope" [32]. Such a highly subjective method of doline delineation was applied as it was established to be more reliable than automated methods [36]. In the case of very shallow depressions, detection of dolines on DEM proved more reliable than field detection. Due to the inexpressive rims of those dolines, field determination of the perimeter was more problematic than 
remote determination. Field and remote data were more accordant in the case of deep depressions. On the basis of these findings, all the input data (presence, location, and shape of dolines) and the attributes of dolines (circularity, planar size, depth) that were employed in the following spatial analyses, were acquired only from the $1 \times 1 \mathrm{~m}$ grid DEM generated from the high-resolution LiDAR data, by the tool "Point to raster" by ArcGIS, which directly assigns the point value to the raster pixel. The highly circular nature of the depressions comprised within the given dataset prompted the use of a circularity index that described those features most accurately [36]. The density index was calculated to include the size of dolines, since dolines treated as points can give misleading results. When big dolines are close to each other, the points representing their centers are as far apart as their radiuses (Figure 2d). In this case, the distance between the centers of depressions 1 and 2 is the same as the distance between the centers of depressions 2 and 3, while the distance between the depressions as entities is different. Thus the density of a depression as the ratio between the area of the depression and the area of the belonging Voronoi polygon was calculated (i.e., density index). Morphometrical and distributive analyses (Table 2) were carried out on a total of 279 depressions.

Spatial analyses were performed using a $1 \times 1 \mathrm{~m}$ grid DEM generated from LiDAR data [37]. The point density of LiDAR data for the study area was $5 \mathrm{pt} / \mathrm{m}^{2}$ with up to $30 \mathrm{~cm}$ horizontal and up to $15 \mathrm{~cm}$ vertical precision [38]. LiDAR data was filtered with a gLiDAR tool [39] by extracting the most-contrasted connected components in order to remove the non-ground objects $[40,41]$.

Table 2. The investigated characteristics of depressions on conglomerates and methods employed in morphometrical and distributive analyses.

\begin{tabular}{|c|c|c|c|}
\hline & Doline Characteristic & Parameter & Method \\
\hline \multirow[t]{3}{*}{$\begin{array}{l}\text { Morphometrical } \\
\text { analyses }\end{array}$} & $\begin{array}{l}\text { The circularity of the } \\
\text { planar shape }\end{array}$ & $\begin{array}{l}\text { Circularity } \\
\text { index }(I c)\end{array}$ & $\begin{array}{l}\qquad \frac{P c c}{P d} \\
\text { where } \\
P c c=\text { The circumference of the } \\
\text { circumscribed circle } \\
P d=\text { The perimeter of the doline } \\
\text { (Figure 2a) }\end{array}$ \\
\hline & $\begin{array}{l}\text { The size of the planar } \\
\text { shape }\end{array}$ & $A$ & $\begin{array}{l}\text { The area of the doline planar shape }\left(\mathrm{m}^{2}\right) \\
\text { (Figure } 2 \mathrm{~b} \text { ) }\end{array}$ \\
\hline & Depth & $h$ & $\begin{array}{l}\text { The vertical distance }(\mathrm{m}) \text { between the } \\
\text { highest elevation of the doline rim and } \\
\text { the lowest elevation of the doline } \\
\text { bottom (Figure } 2 \mathrm{c} \text { ) }\end{array}$ \\
\hline $\begin{array}{l}\text { Distributive } \\
\text { analyses }\end{array}$ & $\begin{array}{l}\text { Density including the } \\
\text { size of dolines }\end{array}$ & $\begin{array}{l}\text { Density index } \\
\text { (Id) }\end{array}$ & $\begin{array}{l}\qquad \frac{A d}{A v} \\
\text { where } \\
A d=\text { The area }\left(\mathrm{m}^{2}\right) \text { of the doline planar } \\
\text { shape } \\
A v=\text { The area }\left(\mathrm{m}^{2}\right) \text { of the zone where } \\
\text { any location is closer to its associated } \\
\text { doline than to any other doline (Voronoi } \\
\text { polygon) }\end{array}$ \\
\hline
\end{tabular}



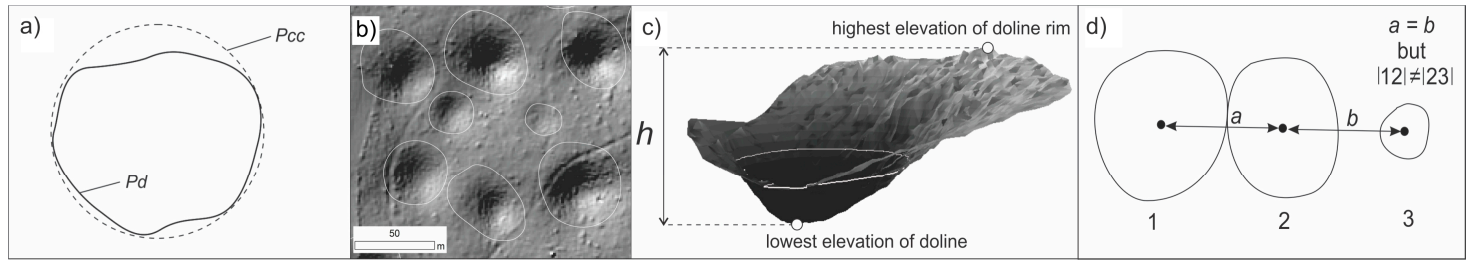

Figure 2. (a) The parameters of a doline circularity index; (b) The area of a doline planar shape, visually determined from LiDAR data; (c) The acquisition of the depth parameter; (d) The influence of doline size on density calculation.

\subsection{Ground Penetrating Radar}

Ground penetrating radar is a non-invasive technique that has engineering, environmental, glaciological, and archaeological applications. Numerous studies describe the successful application of different geophysical techniques to characterize the internal geometry of dolines, providing better understanding of their formation and evolution. Among them, the GPR method provides the highest resolution images. It has been widely used to image the structure of dolines and to locate the potential collapse dolines [42-48].

GPR can be an appropriate tool in many new sub-disciplines that have emerged over the last 15 years, such as forensic geophysics, bio-geophysics, and agro-geophysics [49]. Recently, many studies describe the application of GPR to investigate soil moisture/water content and to determine the extent and lateral variations of soil horizons and their properties [50-55]. Since the thickness of soil cover at the study area exceeds $5 \mathrm{~m}$, knowledge of soils and soil properties is essential to understand the effectiveness of GPR. The chemical, physical, mineralogical, and electromagnetic properties influence the propagation velocity, attenuation, and penetration depth of electromagnetic energy [49].

The electrical conductivity of soils increases with increasing water, soluble salt, and/or clay contents and is governed not only by the amount of clay particles, but also by the types of clay minerals [56]. In the granitic terrain, it was established that the mineralogical composition and the abundance of the minerals strongly influence the depth of penetration where the increased biotite content in regolith restricts GPR performance [54]. According to all mentioned factors, depth penetration in different soils varies from $30 \mathrm{~m}$ in clay-free sands to less than $0.5 \mathrm{~m}$ in wet clayey soils [57,58].

The boundaries which separate soil horizons are usually associated with differences in moisture contents, physical (texture and bulk density) and/or chemical properties. GPR can therefore be used to detect the boundaries between subsurface horizons [49]. However, if electrical properties are similar, different horizons and sometimes even boundaries between soil materials and bedrock are indistinguishable on radar profiles [58]. Some diagnostic surface pedological horizons, such as the argillic horizon (Bt), have a distinctly higher clay content than the overlying horizon and radar signals are rapidly attenuated at the boundary. Therefore, GPR can be a successful tool for estimating the depth to Bt horizons, which have well-defined upper boundaries that display abrupt increases in bulk density and illuviated silicate clays ([49] and references therein). Due to the increase of clay content and bulk density, a Bt horizon generally provides smooth, continuous reflectors on the GPR data that occur at uniform depths [49].

\section{The GPR Survey and Data Processing}

The ProEx (MALA Geoscience, Sweden) ground penetrating radar with an RTA (Rough Terrain Antennas) unshielded $50 \mathrm{MHz}$ bistatic antenna was used with a common offset technique. The length of the GPR system with a flexible snake-like design is $9.25 \mathrm{~m}$, and the spacing between the receiver and the transmitter is $4 \mathrm{~m}$ [59]. In addition, a $250 \mathrm{MHz}$ bistatic shielded antenna was used. 
GPR profiles were recorded at all three test sites (Figure 1) over cultivated and uncultivated dolines to quantify the anthropogenic shape modifications. Profiles were acquired at cultivated areas Poljšica (old conglomerate) and Dobrava (middle conglomerate) to reveal the anthropogenic impact on the depth of the dolines (Profiles 1 and 2). Profile 3 was recorded on the young conglomerate above a roadcut to obtain the contact between the soil and conglomerate bedrock where the soil cover is significantly thinner than the soil cover on the old and middle conglomerate, and mainly does not exceed $2 \mathrm{~m}$. This profile was recorded as a testing profile where the contact is visible on the terrain to correlate the results obtained from Profile 4. On the young conglomerate at Podbrezje, dolines are not clearly expressed on cultivated areas; only the profile over the uncultivated doline in the forest was measured to obtain the primary shape of the doline (Profile 4).

All profiles were measured in two directions perpendicular to each other with a $50 \mathrm{MHz}$ and $250 \mathrm{MHz}$ antenna. It turned out that the unshielded $50 \mathrm{MHz}$ antenna gave more useful results due to better depth of penetration, especially on the old and middle conglomerate, where soil cover is thicker than $5 \mathrm{~m}$. The profiles measured in the forest contain too much noise from the trees due to the unshielded antenna. Here, the shielded $250 \mathrm{MHz}$ antenna provided more useful information, mostly on the young conglomerate, where soil cover is relatively thin and the depth of penetration is around 6-7 $\mathrm{m}$. Selected profiles and their basic data are summarized in Table 3.

Table 3. Basic data of the presented GPR profiles acquired with the $50 \mathrm{MHz}$ unshielded and $250 \mathrm{MHz}$ shielded antennas.

\begin{tabular}{ccccc}
\hline Profile & Location & Type & Length (m) & Antenna Frequency \\
\hline Profile 1 & Poljšica (old conglomerate) & cultivated doline & 46.4 & $50 \mathrm{MHz}$ \\
Profile 2 & Dobrava (middle conglomerate) & cultivated doline & 57.4 & $50 \mathrm{MHz}$ \\
Profile 3 & Podbrezje (young conglomerate) & soil/conglomerate & 79.5 & $250 \mathrm{MHz}$ \\
Profile 4 & Podbrezje (young conglomerate) & uncultivated doline & 64.4 & $250 \mathrm{MHz}$ \\
\hline
\end{tabular}

The profiles were processed with the ReflexW program. The following processing steps were applied: subtract-mean (dewow), time zero correction, background removal, manual gain, bandpass filtering, and topographic correction. The velocity used to convert the two-way travel time into depth was different depending on the expected prevailing material and the depth of penetration for each frequency. In Profiles 1 and 2, the signal did not reach the underlying conglomerate due to several meters of soil, thus the velocity for average soil was used according to the values in the literature $\left(\varepsilon_{\mathrm{r}}=16 ; v=0.075 \mathrm{~m} / \mathrm{ns} ;[49,60]\right)$. In Profile 4 , several hyperbolic diffractions occur below the soil in the conglomerate basement. By hyperbola fitting, velocities between $0.10-0.08 \mathrm{~m} / \mathrm{ns}$ were observed. An average velocity $v=0.09 \mathrm{~m} / \mathrm{ns}$ was used to convert two-way travel time in Profiles 3 and 4 . In the literature, there is no standard value for velocity in such material, but the expected velocity for a carbonate conglomerate should be lower than in carbonates due to the heterogeneous composition causing diffraction and signal scattering. The velocity obtained in Profile 4 could represent the relevant velocity for conglomerate.

\section{Study Area and Test Sites}

\subsection{GPR Results and Defining the Appropriate Test Dolines for Morphometrical Analyses}

The DEM derived from the LiDAR data already indicates the morphological difference between cultivated and uncultivated dolines (Figure 3). Cultivated dolines are shallower and their primary form was reshaped by anthropogenic tilling. On old conglomerate, the depth of uncultivated dolines is 6-8 m, while the depth of cultivated dolines is $4-5 \mathrm{~m}$. The slopes of the cultivated dolines are less steep and smoother due to anthropogenic tilling.

Laterally continuous strong reflectors are visible in Profiles 1 and 2 (Figures 4 and 5). They most likely belong to the argillic horizon $(\mathrm{Bt})$ related to clay accumulation, because its depth corresponds 
to the data observed by a previous study [22]. Following the inventory of the complete soil profiles obtained on conglomerates of different ages in the area, the Bt horizon occurs at an approximate depth of 0.3-0.6 m below the surface and underneath the pedological A or B horizon [22]. The thickness of this horizon amounts to $2.5 \mathrm{~m}$ on young conglomerate and more than $3 \mathrm{~m}$ on middle and old conglomerates [22].

The difference in the dielectric constant between the upper horizon (generally A or AB horizon according to Pavich and Vidic [22]) and the Bt horizon due to the clay and moisture content in the Bt horizon leads to the strong reflectivity at the boundary between horizons. The Bt horizon causes strong signal attenuation and presents the limit of depth penetration.

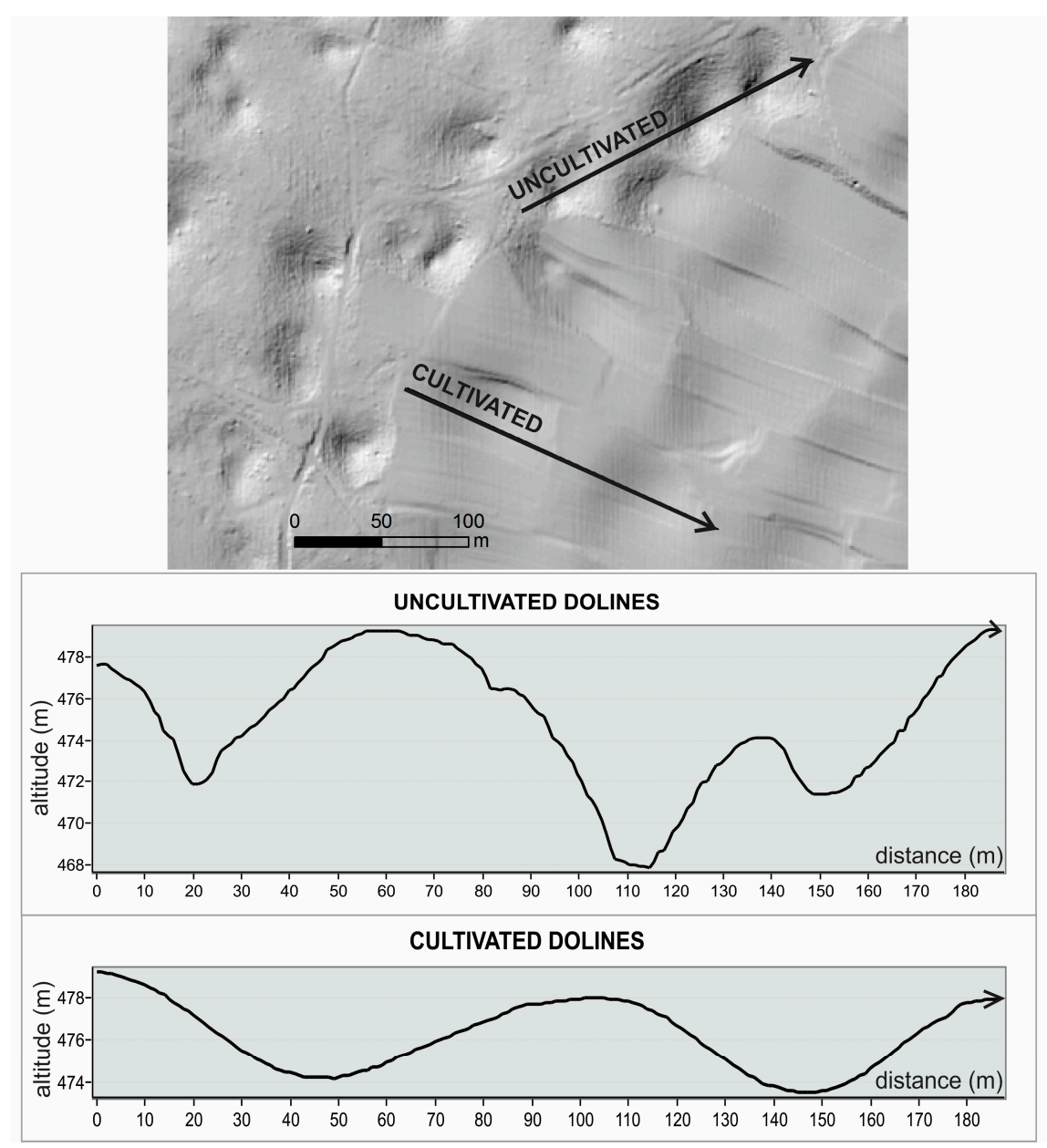

Figure 3. Topographic profiles across cultivated and uncultivated dolines at Poljšica field site [37].

Subsurface horizons are normally parallel and uniform so their shape can be an indirect indicator of agricultural changes in dolines. If the horizons within a doline appear at the same depth as in the surrounding area, the shape of the Bt horizon can provide information about the thickness of the redeposited material, as well as the shape and depth of the doline before cultivation. A slightly undulating reflector within a doline indicates that the primary doline was deeper (Figures 4 and 5). On Profiles 1 and 2, the depth of the redeposited material above the Bt horizon can be roughly evaluated. The maximum thickness of the redeposited material is $2.5 \mathrm{~m}$, considering the dielectric constant for the average soil. This corresponds to the difference between the depths of cultivated and uncultivated dolines derived from DEM. Soil from the slopes was partially terraced and partially moved to the bottom of the dolines to acquire a larger area and to lower the inclination of the slopes. Based on the 
GPR data, the redeposited soil was mixed with more sandy material because the signal penetrates well through it.

Another explanation for the irregular upper boundary of the Bt horizon can be attributed to the underlying dissolution features that are associated with karst processes in conglomerate basement [53]. However, this interpretation is unlikely because the reflector representing the Bt horizon is too smooth and continuous for its shape to be the consequence of the karstification processes under dolines. Furthermore, the estimated thickness of the redeposited material corresponds well with the depths derived from DEM.
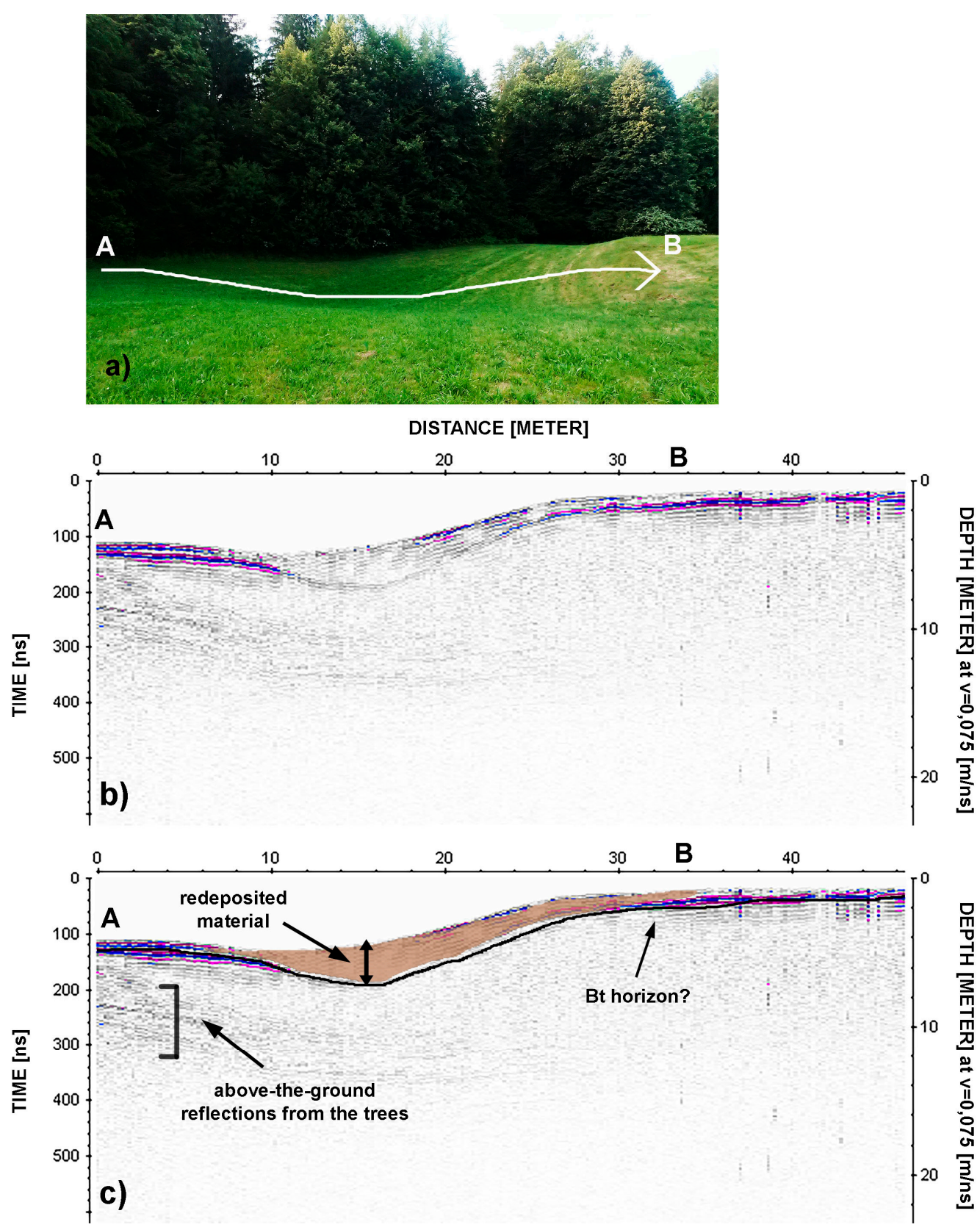

Figure 4. (a) The direction of Profile 1 acquired over a cultivated doline on old conglomerate (Poljšica). The right side of the doline is slightly terraced; (b) A processed and topographically corrected radargram; (c) An interpreted radargram. 

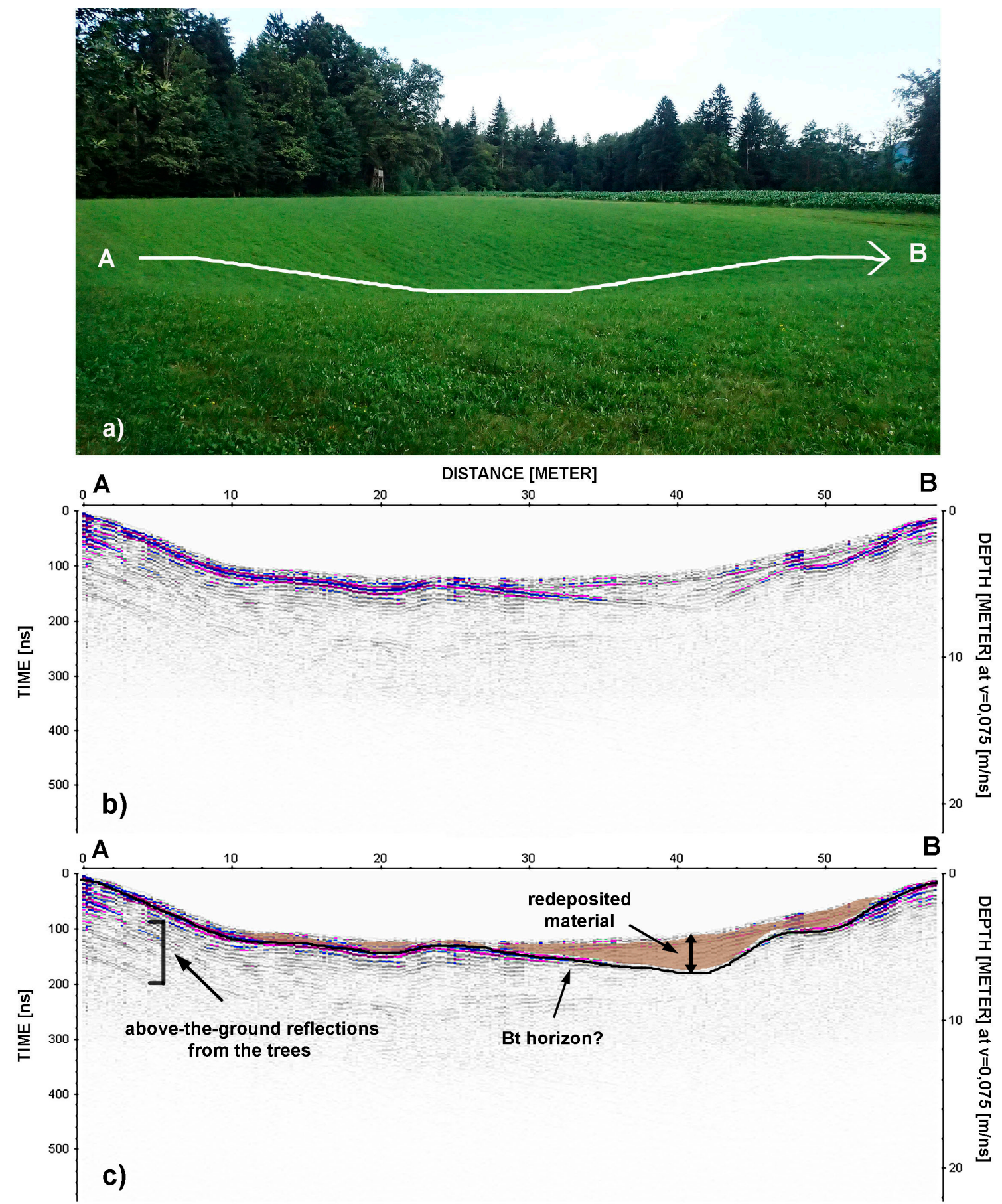

Figure 5. (a) The direction of Profile 2 acquired over a cultivated doline on middle conglomerate (Dobrava); (b) A processed and topographically corrected radargram; (c) An interpreted radargram.

The contact between the soil cover and conglomerate basements is mostly very irregular, forming pockets and bulges (Figure 6A). Profile 3 was measured to observe the contact between the soil cover and the conglomerate bedrock on young conglomerate over a roadcut, where the soil cover is relatively thin (up to $2 \mathrm{~m}$ ). The boundary between the soil and conglomerate is unclear on the GPR data due to the uneven contact and insufficient difference in dielectric properties related to the gradual transition of soil into the conglomerate basement (Figure 6). If the contrast in dielectric properties is too low or the difference is not sudden enough, no distinct reflections are found on the GPR data. 
In order to confirm the primary shape of cultivated dolines acquired with GPR, an uncultivated doline on young conglomerate was also measured (Profile 4, Figure 7). The soil cover on young conglomerate is significantly thinner, so the contact between the soil and conglomerate can provide some information about the primary shape of the doline.

The radargram of Profile 4 shows that no distinctive reflector is visible that could represent the Bt horizon as in Profiles 1 and 2. Similarly, the soil/bedrock interface over the uncultivated doline is not clearly expressed as high-amplitude reflections, but is distinguishable in the form of occurrences of hyperbolic diffractions (Figure 7). They are the consequence of cavities and fractures within a karstified carbonate conglomerate. The soil/bedrock interface is unclear due to the presence of coarse fragments or blocks in the overlying soil, irregular bedrock surfaces, and fracturing that are characteristic of karst on carbonates and on conglomerates.

The boundary soil/bedrock (highlighted by the dashed line in Figure 7) is defined by hyperbolic anomalies. The thickness of the soil cover varies between 1 and $3 \mathrm{~m}$, which corresponds with the known soil thickness on young conglomerate [22].

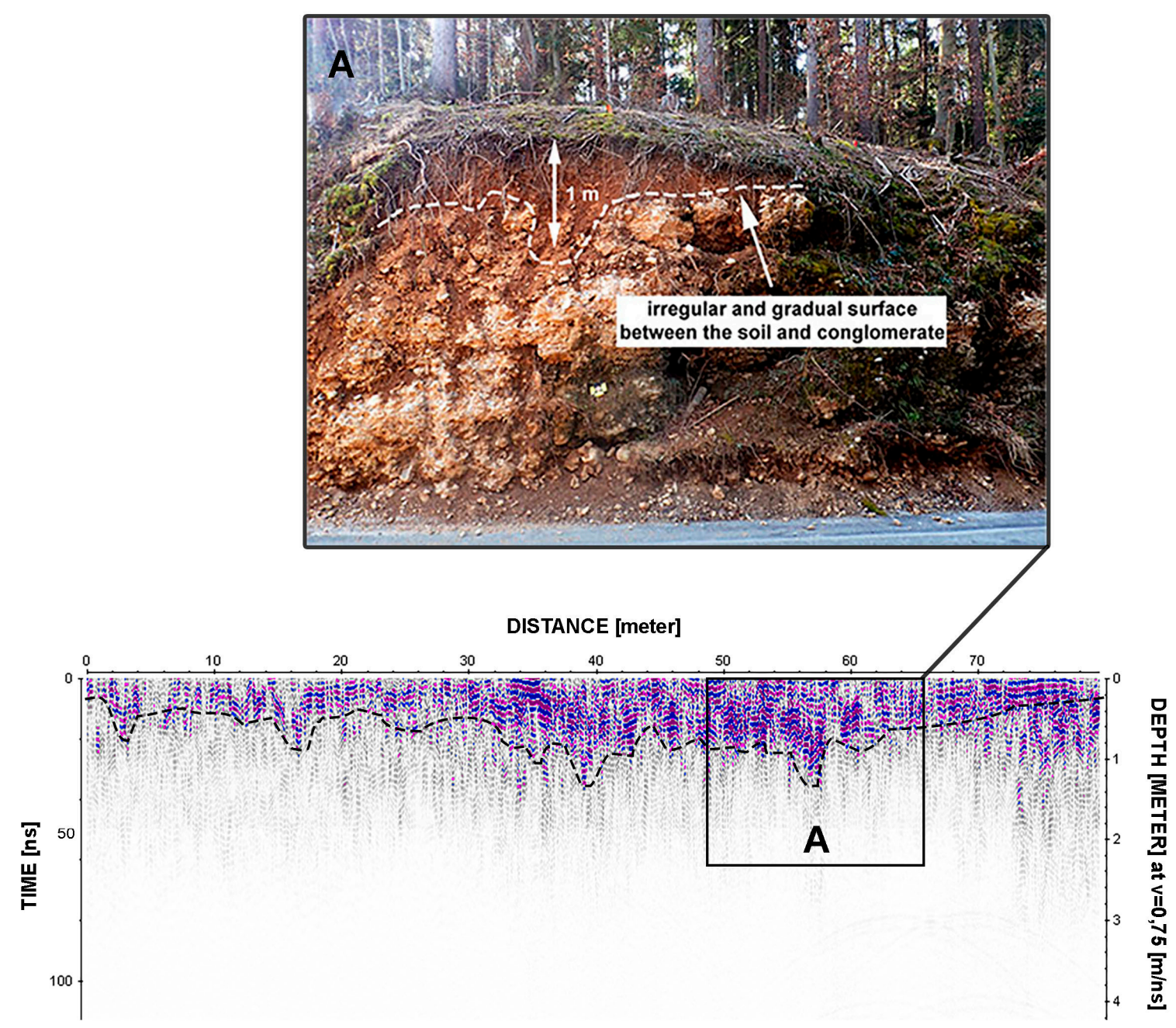

Figure 6. Profile 3: The contact between the soil cover and conglomerate bedrock on young conglomerate (Podbrezje) above a roadcut, using a $250 \mathrm{MHz}$ antenna. Vertical exaggeration 1:6. 

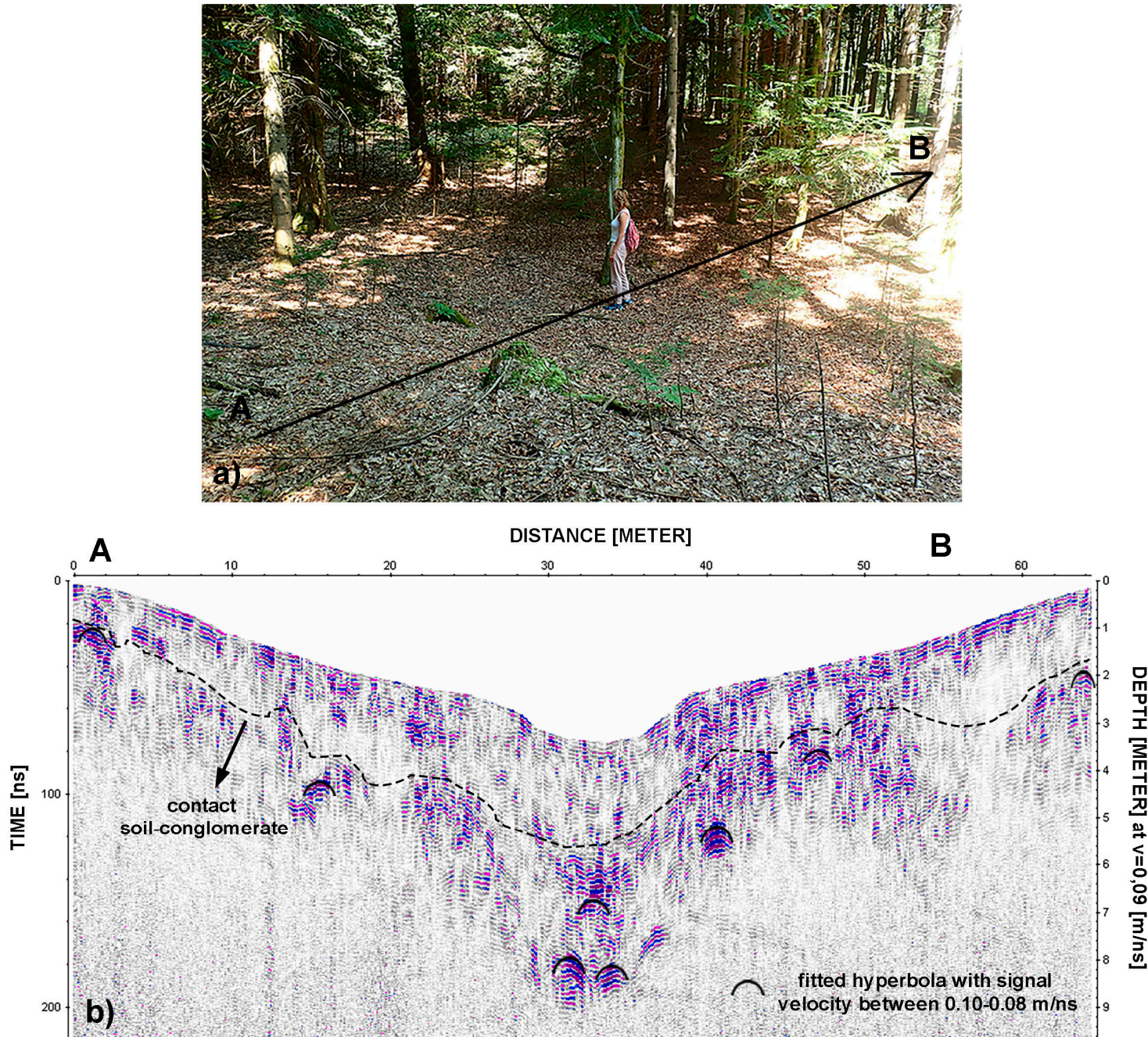

Figure 7. (a) The direction of Profile 4 acquired with a $250 \mathrm{MHz}$ antenna over an uncultivated doline on young conglomerate (Podbrezje); (b) The soil/bedrock boundary is estimated by the appearance of hyperbolic diffractions caused by cavities and fractures within carbonate conglomerate. Vertical exaggeration 1:3.

A simplified model of anthropogenic reshaping of the doline was constructed using the detected Bt horizon on the GPR data from cultivated dolines (Figure 8). The primary shape of dolines is difficult to reconstruct. The primary depth of dolines can be approximately obtained from the GPR data, but that kind of determination is very time-consuming when a large number of dolines must be measured. GPR results show considerable morphological modifications of dolines due to anthropogenic intervention, as cultivated dolines are approximately $2 \mathrm{~m}$ shallower than uncultivated ones. This is why dolines on cultivated areas were excluded from further spatial analyses. 
1. The primary shape of the doline

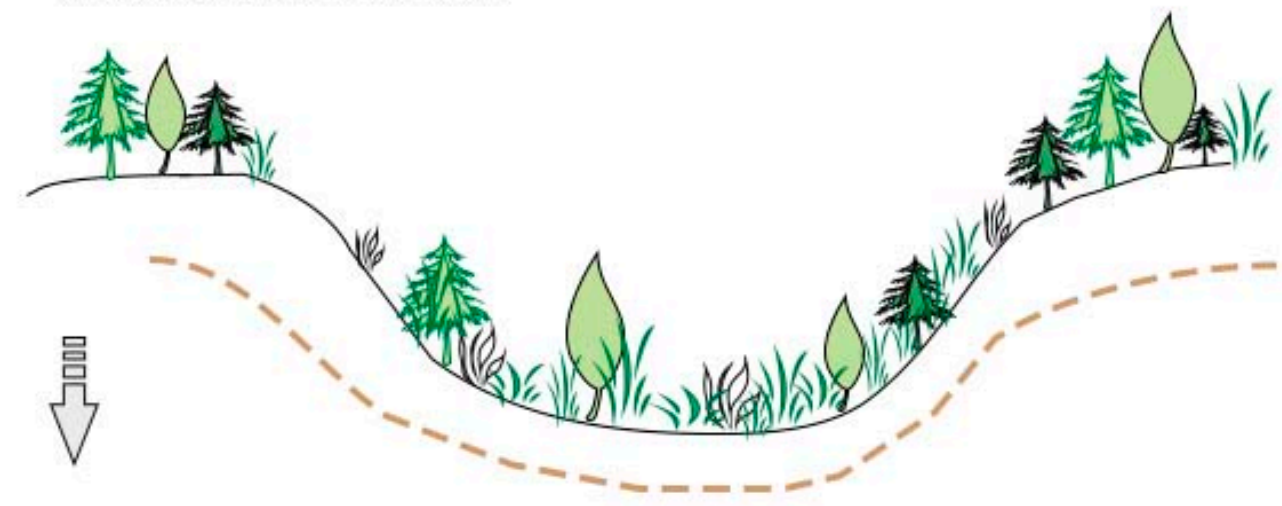

2. Doline reshaping due to anthropogenic tilling

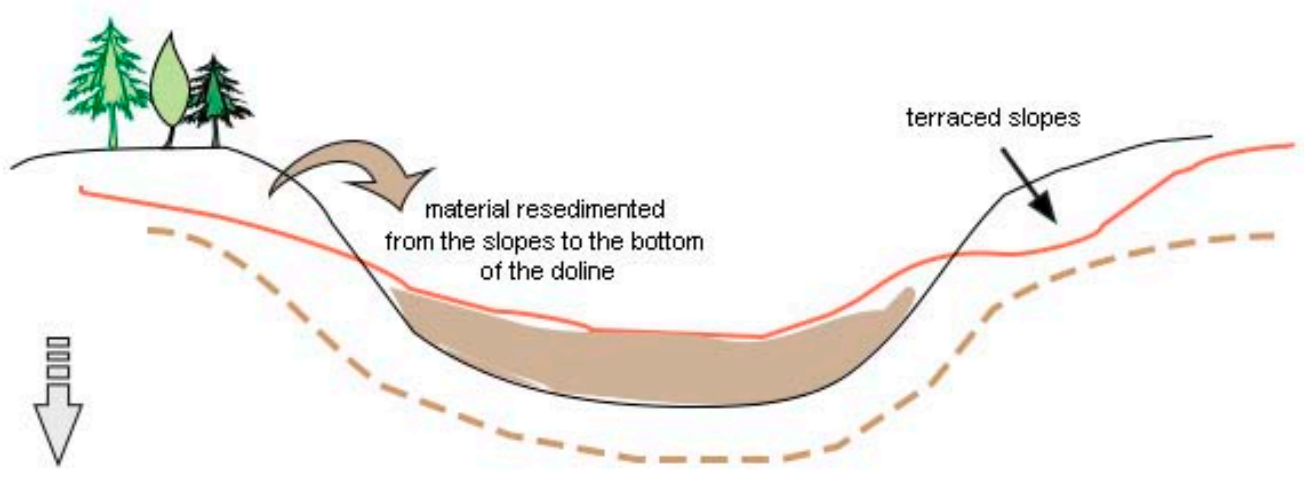

3. The current shape of the doline

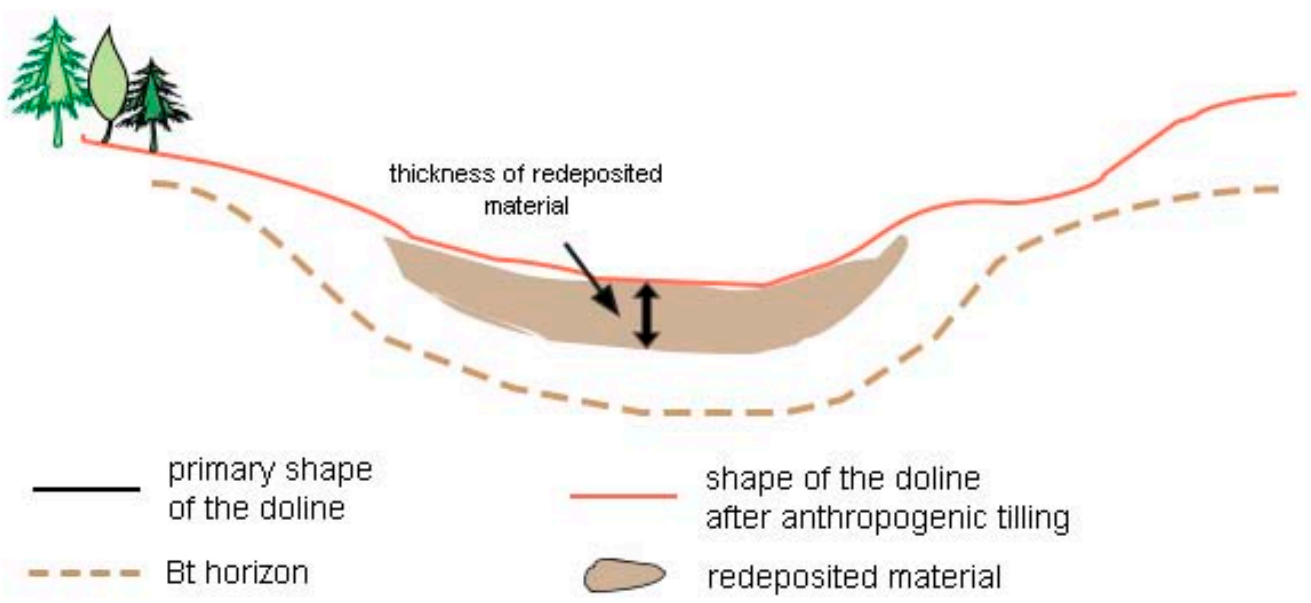

Figure 8. A simplified model of agriculturally reshaped dolines. The Bt horizon in the current form of the doline as detected by the GPR survey indicates the redeposited material.

\subsection{Test Sites for Spatial Analyses}

Study sites on three different conglomerates (young, middle, and old) were selected on the basis of the maps done by Žlebnik [2], and Pavich and Vidic [22] on locations where the dating of both authors was accordant (Table 4) and where the surface is forested. They are at most $1.5 \mathrm{~km}$ apart and are separated by the valleys of the Sava and Lipnica rivers (Figure 9) which flow at the elevation of approximately $380 \mathrm{~m}$. The oldest conglomerate (Poljšica) is at the altitude $470-490 \mathrm{~m}$, similar to 
the middle conglomerate (Dobrava) which is located at $475-485 \mathrm{~m}$, while the youngest conglomerate (Podbrezje) is at a lower altitude (450-460 m). On the basis of DEM examination and GPR data, only dolines on uncultivated areas were subject to spatial analyses.

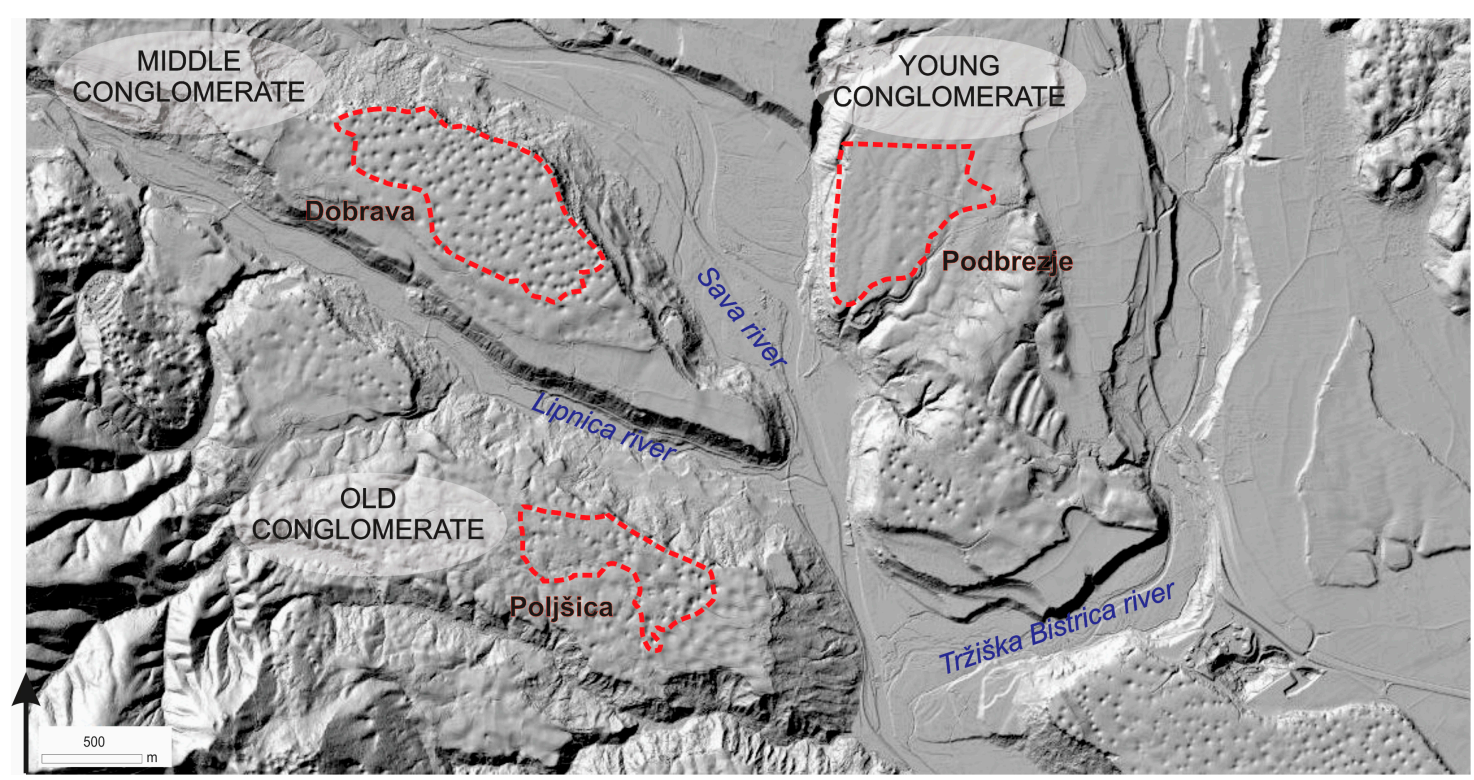

Figure 9. Test sites and relief characteristics as visible from $1 \mathrm{~m}$ resolution LiDAR data [37].

Table 4. Basic statistics of test sites.

\begin{tabular}{cccc}
\hline & Podbrezje & Dobrava & Poljšica \\
\hline Relative age of conglomerate & Young & Middle & Old \\
Area $\left(\mathbf{m}^{\mathbf{2}}\right)$ & 382108 & 775562 & 309349 \\
Number of identified dolines & 21 & 185 & 73 \\
\hline
\end{tabular}

\section{Results}

\subsection{The Circularity of the Doline Planar Shape}

Doline planar shapes are highly circular and uniform on conglomerates of all ages. Mean values of the circularity index (Ic) for doline planar shapes (Figure 10) are 1.104-1.069, being close to the value 1.000 of the circle. The range of the majority of values is similar for all three sites (1.05-1.13), while the irregularity slightly increases with the age of conglomerate, as well as the dispersion of values. Circularity is not linked to the size of a doline planar shape, nor to doline depth (Figure 11). The independence of size and conglomerate age (and other mechanical and chemical properties of the rock) from generally high circularity of dolines indicates that circularity as one of the main characteristics of dolines is linked to external factors of karst surface reshaping, rather than to the temporal aspect of doline evolution. Spatial distribution of dolines classified by planar size does not indicate any particular patterns. 


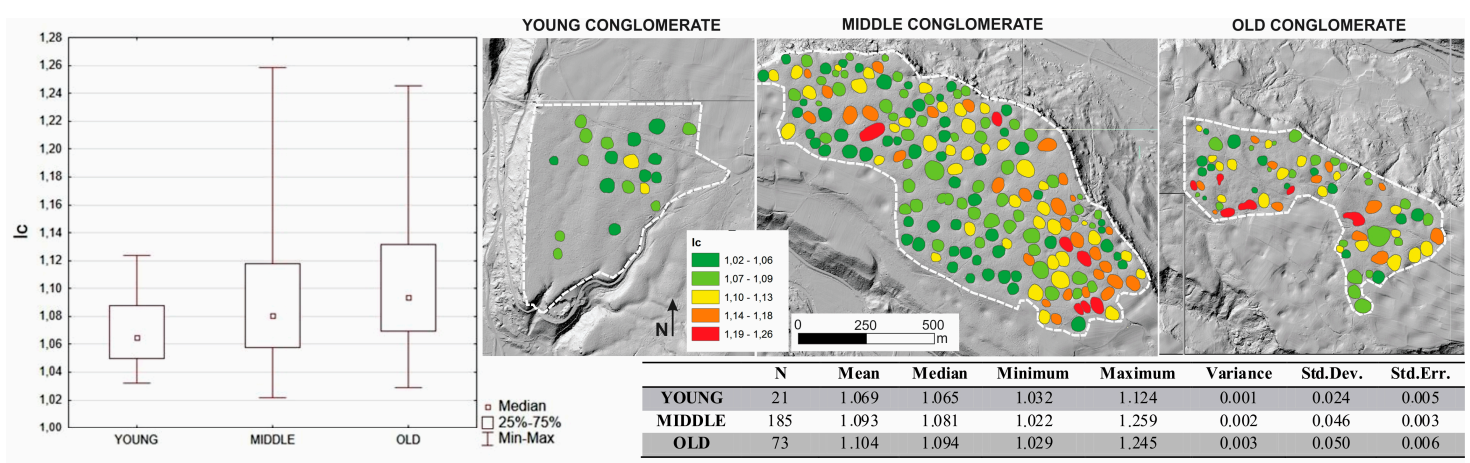

Figure 10. The circularity of dolines' planar shapes for conglomerates by age.
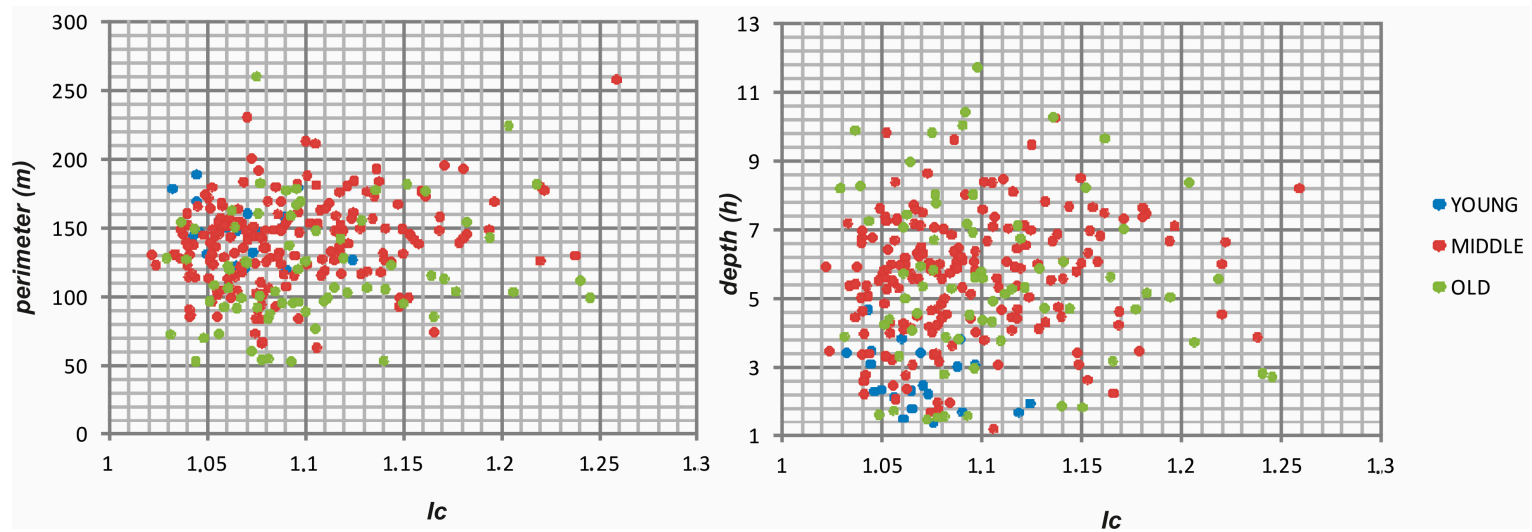

Figure 11. The correlations between circularity index (Ic) and perimeter and depth for conglomerates by age.

\subsection{The Area of the Doline Planar Shape}

Based on the calculated values (Figure 12), the planar size of the dolines on all conglomerates appears as a highly constant characteristic. The majority of values for all ages of conglomerate range from 800 to $1900 \mathrm{~m}^{2}$, which is a very narrow class, while the dispersion of values increases considerably with the age of conglomerate. A slight decrease of doline planar size mean value follows the increasing age of conglomerate due to the appearance of dolines with very small planar size on the old conglomerate. It is of particular interest that the planar size of shallow dolines on young conglomerate (see also Section 5.3) does not deviate noticeably from the planar size of deep dolines on middle or old conglomerate, which means that a doline acquires its planar size in its early stage of development (Figure 13). The same was established by Ferrarese and Sauro [4] for dolines on Montello conglomerate and explained by diffuse porosity in conglomerate rock. The conceptual model applicable to the Dinaric solution dolines was used as a base to calculate that the expansion rate of a doline perimeter decreases with time as the reciprocal of a quadratic function, meaning that the increase of the planar shape size is fast in the beginning and slows down later [61]. A high variability of shapes (see Section 5.1), as well as a high variability of planar sizes were noticeable on old conglomerate, where big and very small dolines occur together. The size is the most uniform on young conglomerate, and the uniformity decreases with the increasing age of conglomerate. Spatial distribution of dolines by planar size does not show any specific patterns. 


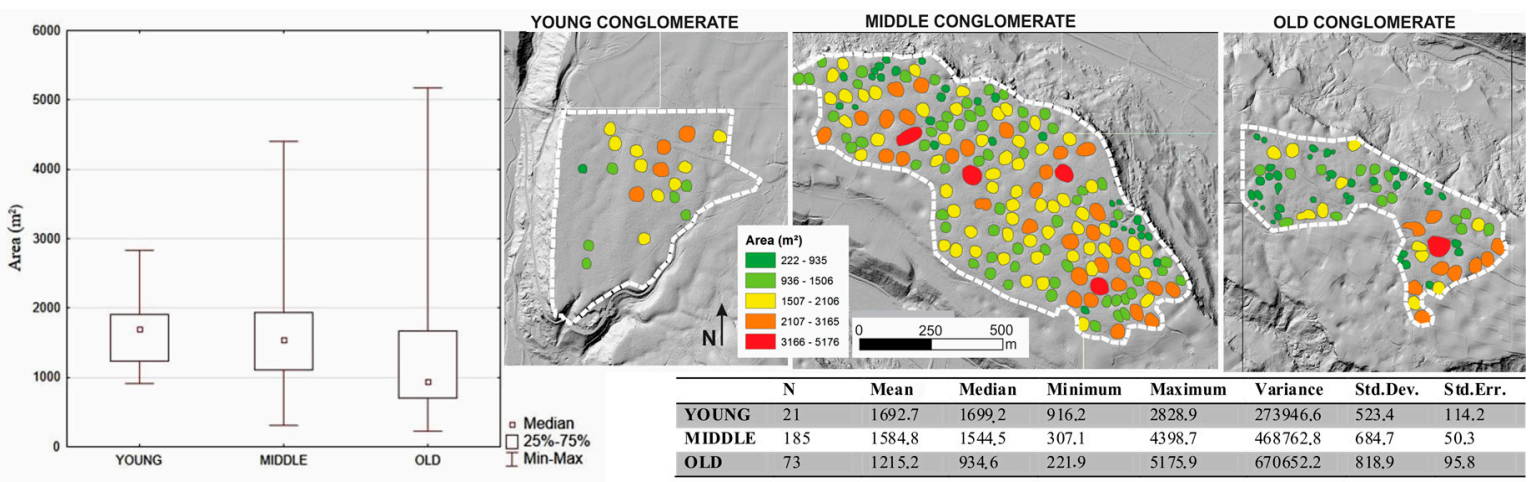

Figure 12. The area of a doline planar shape for conglomerates by age.

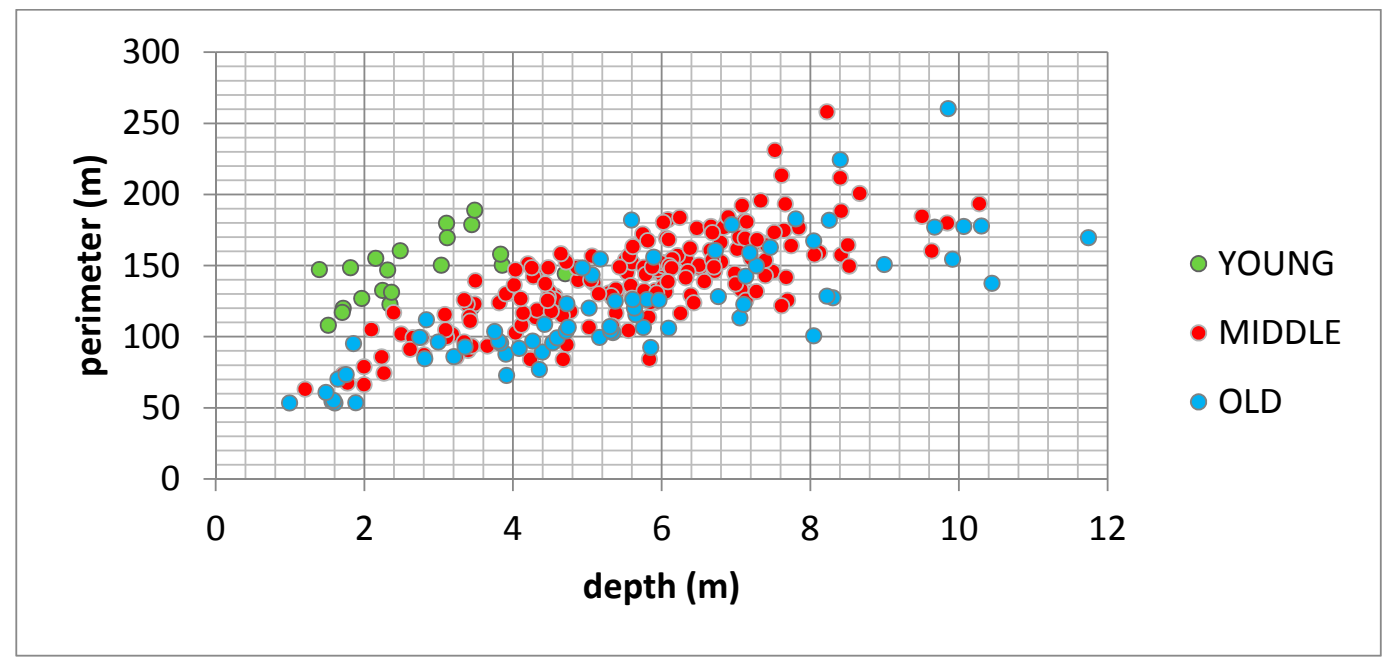

Figure 13. Depth to perimeter relationship for dolines on conglomerates by age.

\subsection{Doline Depth}

The considerable difference in doline depth range is noticeable between young conglomerate on one side, and middle and old conglomerate on the other (Figure 14). Dolines on young conglomerate are shallow (mean $2.7 \mathrm{~m}$ ) and very uniform, deviating only $3.3 \mathrm{~m}$ in depth, while dolines on the other two sites (mean $5.6 \mathrm{~m}$ for middle and $5.5 \mathrm{~m}$ for old conglomerate) are on average much deeper and considerably more varied, deviating as much as $10.8 \mathrm{~m}$ in depth on old conglomerate. Generally, the depth of dolines increases with the increasing age of conglomerate, where the average on old conglomerate is lowered by the presence of very shallow depressions. The increase of doline depth with age is consistent with the usual time-dependent growth of natural phenomena, but shallow dolines on young conglomerate may also be the reflection of relatively slower karstification processes due to less favorable rock properties. Spatial distribution of dolines by depth does not indicate any particular patterns. 


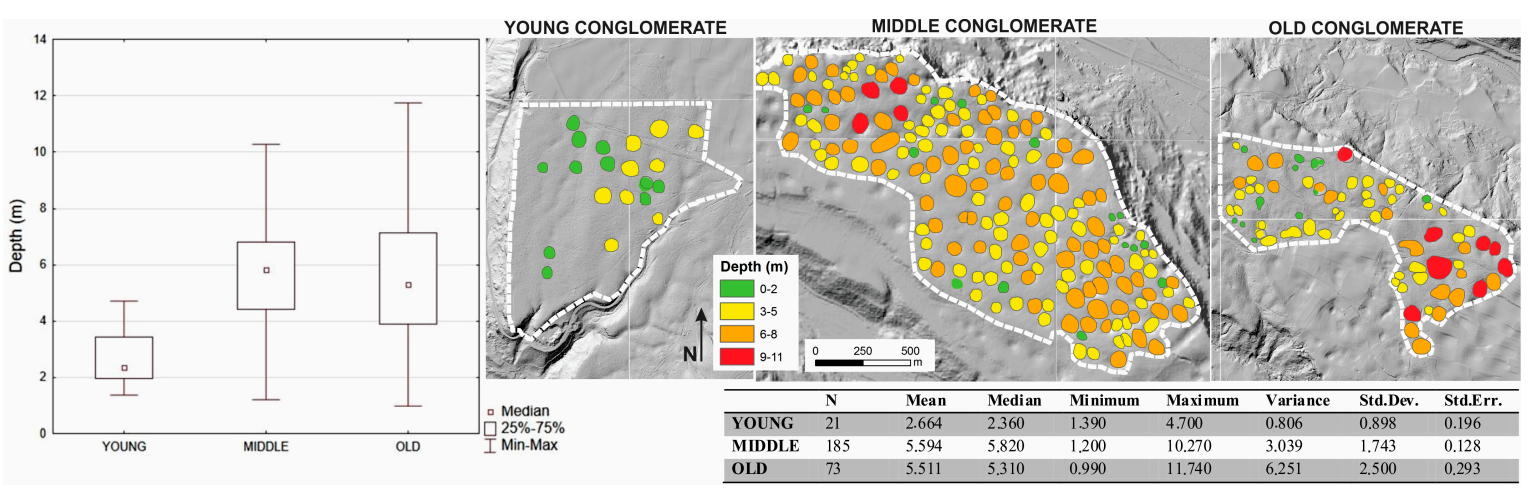

Figure 14. Doline depth for conglomerates by age.

\subsection{Doline Distribution}

Dolines cover $9 \%$ of young conglomerate, $38 \%$ of middle, and $29 \%$ of old conglomerate at the test sites. The density is the lowest (mean 0.152) but quite uniform on young conglomerate. On middle conglomerate, the high density (mean 0.397) is very uniform over the entire test site. Big dolines are especially densely distributed, a phenomenon which is particularly obvious on old conglomerate. Here, density is the least uniform as big dolines are located close to each other, while smaller dolines occupy empty areas where they are spread more uniformly and far apart (Figure 15). This phenomenon is especially evident on old and middle conglomerate. The distribution of dolines is not linked to linear tectonic structures. This was already observed on Montello conglomerate karst [4], where the same authors explained that it stemmed from the predominance of diffuse over fracture porosity. They concluded that the pattern of dolines on conglomerate reflects the influence of morphological elements rather than a fracture network.

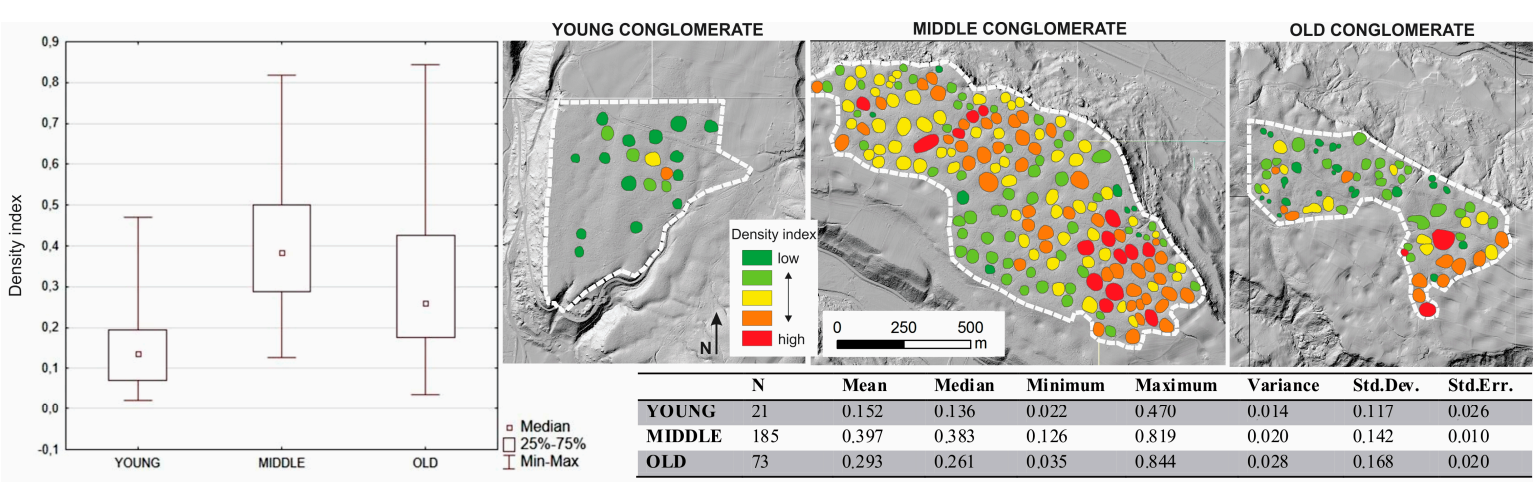

Figure 15. Doline distribution by the age of conglomerate index represented by density index.

\subsection{Typization of Karst Surface Morphology as a Tool for Dating Conglomerates}

Morphometrical and distributive analyses of dolines on unconsolidated carbonate gravel and on old, middle, and young carbonate conglomerates indicate the following general geomorphological characteristics:

- Unconsolidated gravel: the surface is flat with no surface features (Figure 16a).

- Young conglomerate: the surface is flat and characterized by scarce shallow surface features. Shallow linear depressions appear as nearly unrecognizable irregularities. Sporadically, large but shallow dolines develop. In some cases, their location seems to be linked to linear depressions (Figure 16b).

- Middle conglomerate: the surface is rather flat and entirely covered by mainly uniform, funnel-like deep dolines (Figure 16c). 
- Old conglomerate: the surface is irregular; the depressions come in all sizes, depths, and shapes (Figure 16d) and do not entirely cover the surface. The largest and deepest dolines occur here (Type 1), as well as small and shallow (Type 2), and double ones (Type 3).
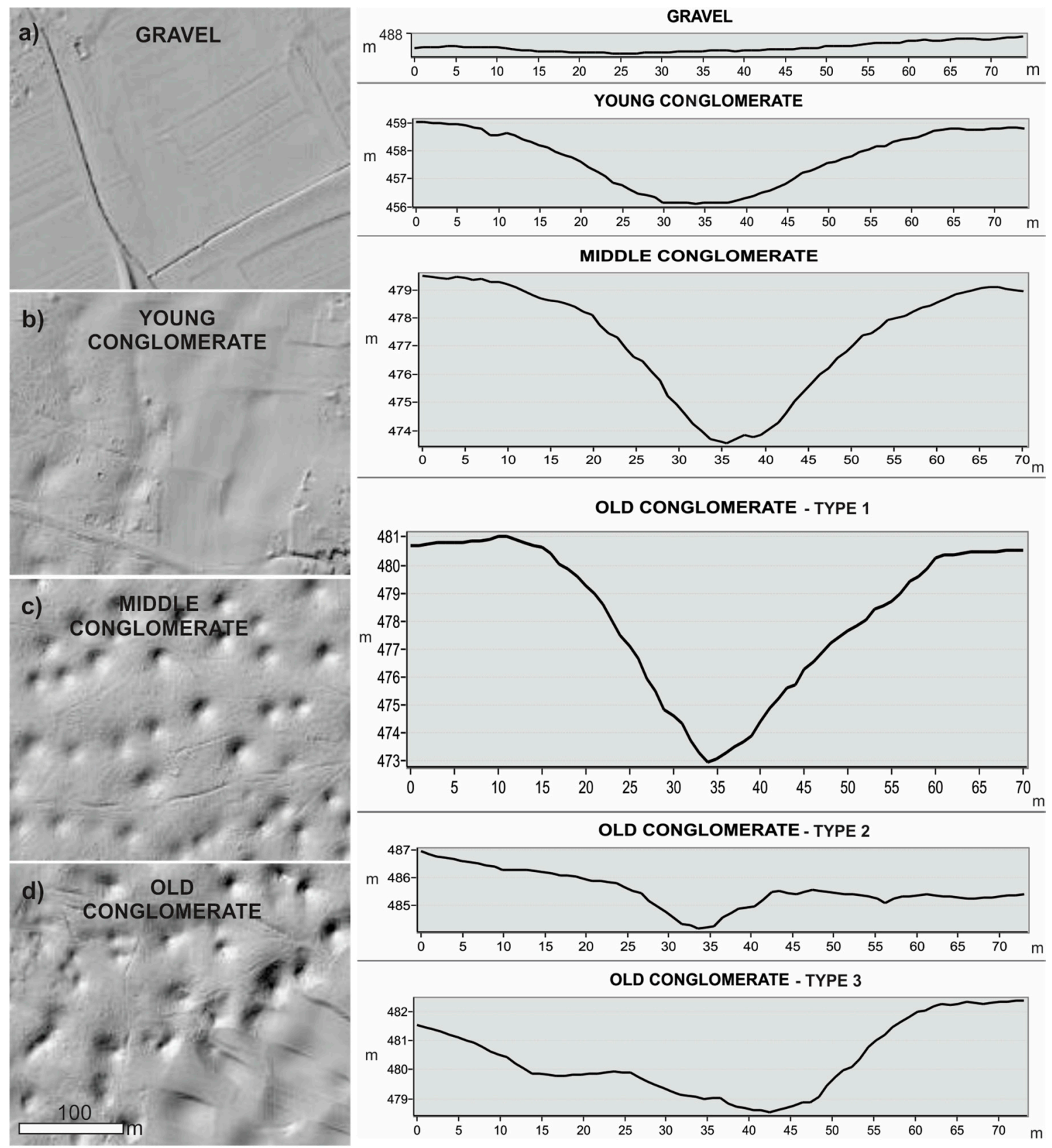

Figure 16. The typical surface morphology of gravel and karstified conglomerates by age with the profiles across characteristic dolines. (a) Gravel: flat surface with no surface features; (b) Young conglomerate: flat surface with scarce shallow surface features (dolines and linear depressions); (c) Middle conglomerate: rather flat surface with uniform dolines of high density; (d) Old conglomerate: irregular surface with depressions of high morphologic heterogeneity (profiles across the three types of dolines).

According to the acquired data, dolines on young conglomerate are the most uniform. They are characterized by large and the most circular planar shapes, while they are the shallowest compared to 
dolines on other conglomerates. Dolines on old conglomerate, however, are the most heterogeneous in each parameter, with the smallest average size and the least regular planar shape. The deepest dolines can be found on this conglomerate, but many shallow dolines also occur. The latter are different from those on young conglomerate, as they are small and more irregular (Table 5).

Table 5. Descriptive morphometrical and distributive characteristics of dolines for karstified conglomerates by age.

\begin{tabular}{lllll}
\hline & & Young Conglomerate & Middle Conglomerate & Old Conglomerate \\
\hline Surface features & shallow linear depressions, dolines & dolines & dolines \\
\hline \multirow{4}{*}{ Dolines } & volumetric shape & bowl-like & funnel-like & $\begin{array}{l}\text { Type 1: funnel-like } \\
\text { Type 2: bowl-like }\end{array}$ \\
\cline { 2 - 5 } & planar shape & highly circular & highly circular & $\begin{array}{l}\text { Type 1: highly circular } \\
\text { Type 2: irregular }\end{array}$ \\
\cline { 2 - 5 } & \multirow{2}{*}{ planar size } & uniform & uniform & $\begin{array}{l}\text { Type 1: uniform } \\
\text { Type 2: small }\end{array}$ \\
\cline { 2 - 5 } & \multirow{2}{*}{ depth } & shallow & $\begin{array}{l}\text { Type 1: deep } \\
\text { Type 2: shallow }\end{array}$ & $\begin{array}{l}\text { Type 1: deep } \\
\text { Type 2: shallow }\end{array}$ \\
\cline { 2 - 5 } & slope & gentle & steep & $\begin{array}{l}\text { Type 1: extremely steep } \\
\text { Type 2: gentle }\end{array}$ \\
\cline { 2 - 5 } & frequency & rare & numerous & moderate \\
\cline { 2 - 5 } & uniformity & high & moderate & low \\
\hline Distribution & & sporadic & covering the entire surface & scattered \\
\hline
\end{tabular}

\section{Discussion}

The visual analysis of shaded relief derived from high-resolution LiDAR data itself already enables the recognition of relief differences on particular ages of carbonate conglomerates. However, morphometrical and distributive spatial analyses of dolines were performed to quantify the specific characteristics that are linked to the age of conglomerate. Noticeable differences in calculated parameters confirmed a satisfactory reliability of visual analysis in distinguishing karstified surfaces on carbonate conglomerates. Based on this, visual analysis was employed to extrapolate the data to the wider conglomerate area in the Ljubljana basin, which proved an easy and fast method for surface classification without time-consuming field examinations. Among all the analyzed parameters, the scarcity and the shallowness of dolines were the most distinctive characteristics of doline population developing on young conglomerates. As the distribution of dolines on middle and old conglomerates may sometimes appear similar, the degree of uniformity of morphometrical properties was the crucial factor for their distinction.

The reliability of geomorphological dating (Figure 17) was tested by comparing the geomorphological characteristics of the analyzed sites to all the areas dated by Žlebnik [2], and Pavich and Vidic [22]. The DEM from the high-resolution LiDAR data shows a high accordance of the surface karstification degree with relative dating based on the morphostratigrafic mapping and borehole data [2], as well as cosmogenic-nuclide burial dating and paleomagnetic methods [22]. The geomorphological dating method fails on very small areas as a certain amount of the surface should be exposed and karstified in order to generalize local morphometrical and distributive characteristics (marked blue in Figure 17).

Discrepancies with Žlebnik's [2] dating were found on two locations (A and B), and on another two with the dating done by Pavich and Vidic [22] (C and D) (Figure 17). A high morphological diversity of features and some extreme doline depths are more closely related to old conglomerate than with middle on Location A, which corresponds with the dating by Pavich and Vidic [22]. On Location B, the distribution of dolines is too dense to belong to young conglomerate, while the shallowness of dolines is due to human impact. After geomorphological dating, this site corresponds to middle conglomerate. Towards the south, the surface lacks any surface irregularities, so it was classified as a Würm gravel fill. Indicating shallow surface irregularities, Locations $C$ and D correspond to 
young conglomerate. Both results of geomorphological dating at Locations $\mathrm{C}$ and $\mathrm{D}$ are in accordance with Žlebnik's dating [2].

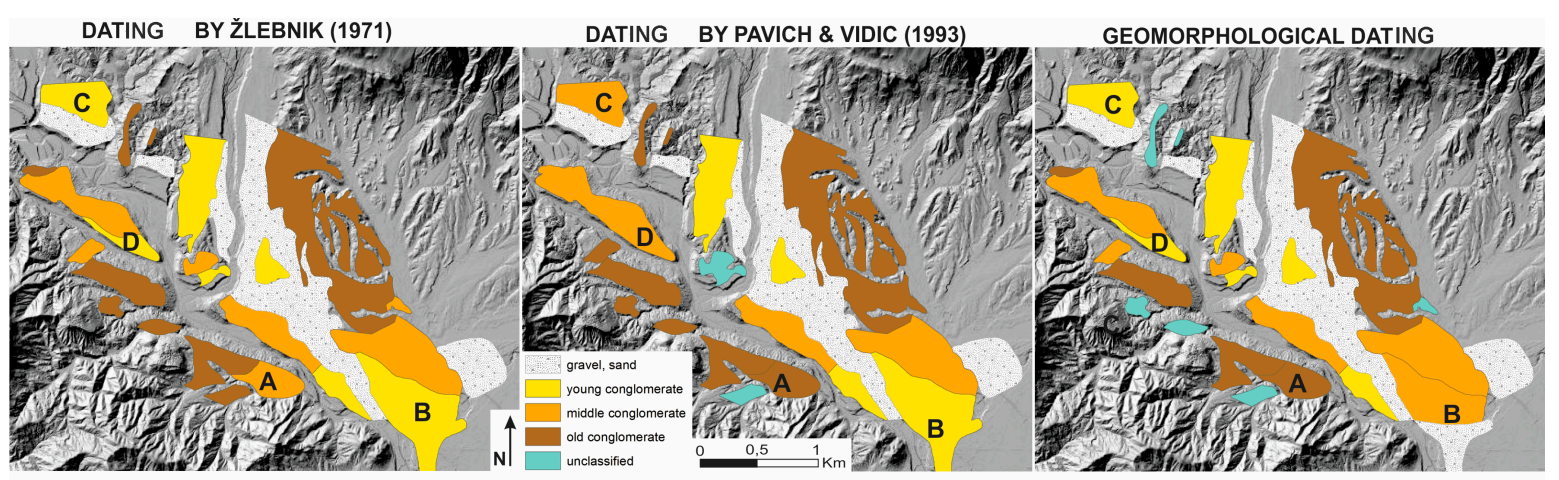

Figure 17. A comparison of geomorphological dating by the type of surface karstification with relative dating based on morphostratigrafic mapping and borehole data by Žlebnik [2] and absolute dating based on paleomagnetic and ${ }^{10} \mathrm{Be}$ analyses by Pavich and Vidic [22] in the wider area of the Ljubljana Basin. Discrepancies in geomorphological dating are marked with A-D.

\section{Conclusions}

Pleistocene conglomerates of different ages in the Ljubljana Basin were subject to different relative and absolute dating methods in the past. The different degrees of karstification, as well as doline shape and depth obtained on the terrain during geological mapping were used as additional indicators for determining the relative age of conglomerate terraces.

Nowadays, LiDAR data with high spatial resolution enables a better detection of dolines and a fast determination of different parameters needed for further morphometrical and distributive spatial analyses. The main purpose of the study was to classify all conglomerate terraces within the Ljubljana Basin on the basis of the geomorphological characteristics of dolines obtained on the three test sites including old, middle, and young conglomerates.

The surface on all three conglomerates is partially forested and also partially cultivated. The ground penetrating radar (GPR) method was used to select the appropriate dolines for further analyses. GPR results confirmed the observations from LiDAR images: cultivated dolines are shallower and have lower slope inclination due to redeposition of soil from the flanks into the doline. GPR data measured over cultivated dolines on old and middle conglomerate proves that cultivated dolines are approximately $2.5 \mathrm{~m}$ shallower in the bottom due to the human tilling, while some dolines are also slightly terraced. For that reason, cultivated dolines were not included in further morphometrical analyses.

Circularity index, planar size, depth, and density index of dolines were calculated at the three test sites for each relative age of conglomerates. Morphometrical and distributive analyses revealed that dolines have typical geomorphological characteristics on each of the conglomerates of a relative age. Results derived at all three test sites were further extrapolated to the wider area of the Ljubljana Basin and compared with relative dating [2] and absolute dating [22] to test the reliability of geomorphological dating. The results of spatial analyses generally confirmed former dating and proved that geomorphological dating can be a fast and reliable method for dating karstified conglomerates. Furthermore, the morphometrical and distributive data obtained from the dolines can be used as a basis for future research analyses aimed at understanding the karstification processes in conglomerates.

Acknowledgments: This study was conducted with the support of the research Program P1-0011 and the Ph.D. grant 1000-15-0510 financed by the Slovenian Research Agency. This work also benefited from networking activities carried out within the EU-funded COST Action TU1208 "Civil Engineering Applications of Ground Penetrating Radar". We would also like to thank Andrej Pipan for field assistance, France Šušteršič for comments 
and advice during the preparation of this paper, and Tomaž Verbič for sharing his field experience related to the geophysical and pedological properties of conglomerates.

Author Contributions: Teja Čeru acquired and processed the GPR data and wrote Section 2, Section 3.2, Section 4.1, and Section 7 and contributed to Sections 1 and 5. Ela Šegina did the morphometrical and distributive spatial analyses and wrote Section 3.1, Section 4.2, Section 5, and Section 6 and contributed to Section 1. Andrej Gosar contributed to GPR measurements and data processing as well as to the preparation of the manuscript.

Conflicts of Interest: The authors declare no conflict of interest.

\section{References}

1. Šifrer, M. Kvartarni razvoj Dobrav na Gorenjskem (The Quarternary development of Dobrave in Upper Carniola (Gorenjska) Slovenia). Geografski Zbornik 1969, 11, 99-221.

2. Žlebnik, L. Pleistocen Kranjskega, Sorškega in Ljubljanskega polja. Geologija 1971, 14, 5-51.

3. Knez, M.; Šebela, S.; Gabrovšek, F. Geološke osnove ter jame (Geological settings and caves). In Udin Boršt; Kranjc, A., Ed.; Museo di Storia Naturale e Archeologia: Montebelluna, Italy, 2005; pp. 9-24.

4. Ferrarese, F.; Sauro, U. The Montello Hill: The "classical karst" of the conglomerate rocks. Acta Carsol. 2005, 34, 439-448. [CrossRef]

5. Telbisz, T.; Látos, T.; Deák, M.; Székely, B.; Koma, Z.; Standovár, T. The advantage of lidar digital terrain models in doline morphometry compared to topographic map based datasets-Aggtelek karst (Hungary) as an example. Acta Carsol. 2016, 45, 5-24. [CrossRef]

6. Pardo-Igúzquiza, E.; Valsero, J.J.D.; Dowd, P.A. Automatic detection and delineation of karst terrain depressions and its application in geomorphological mapping and morphometrical analysis. Acta Carsol. 2013, 42, 17-24. [CrossRef]

7. Carvalho, O.D.; Guimarães, R.; Montgomery, D.; Gillespie, A.; Gomes, R.T.; Martins, É.D.S.; Silva, N. Karst depression detection using ASTER, ALOS/PRISM and SRTM-Derived digital elevation models in the Bambuí Group, Brazil. Remote Sens. 2013, 6, 330-351. [CrossRef]

8. Kobal, M.; Bertoncelj, I.; Pirotti, F.; Kutnar, L. Lidar processing for defining sinkhole characteristics under dense forest cover: A case study in the Dinaric mountains. Int. Arch. Photogramm. Remote Sens. Spat. Inf. Sci. 2014, 40, 113-118. [CrossRef]

9. Jeanpert, J.; Genthon, P.; Maurizot, P.; Folio, J.-L.; Vendé-Leclerc, M.; Sérino, J.; Join, J.-L.; Iseppi, M. Morphology and distribution of dolines on ultramafic rocks from airborne LiDAR data: The case of southern Grande Terre in New Caledonia (SW Pacific). Earth Surf. Process. Landf. 2016, 41, 1854-1868. [CrossRef]

10. Černatic-Gregorič, A.; Zega, M. The impact of human activities on dolines (sinkholes): Typical geomorphologic features on Karst (Slovenia) and possibilities of their preservation. Geogr. Pannonica 2010, 14, 109-117. [CrossRef]

11. Breg Valjavec, M.; Zorn, M. Degraded karst relief: Waste-filled dolines. In Advances in Environmental Research, 1st ed.; Daniels, J.A., Ed.; Nova Science Publishers: New York, NY, USA, 2015; Volume 40, pp. 77-95.

12. Gabrovšek, F. Jame v konglomeratu: Primer Udin Boršta, Slovenija. (Caves in conglomerate: Case of Udin Boršt, Slovenia). Acta Carsol. 2005, 34, 507-519.

13. Gantar, J. Arneševa luknja. Acta Carsol. 1995, 1, 151-158.

14. Šter, D. Udin Boršt in njegov kras. Proteus 1995, 57, 237-244.

15. Lipar, M.; Ferk, M. Eogenetic caves in conglomerate: An example from Udin Boršt, Slovenia. Int. J. Speleol. 2011, 40, 53-64. [CrossRef]

16. Ferk, M.; Lipar, M. Eogenetic caves in Pleistocene carbonate conglomerate in Slovenia. Acta Geogr. Slov. 2012, 52, 7-33. [CrossRef]

17. Grad, K.; Ferjančič, L. Basic Geological Map of Yugoslavia, Sheet Kranj, L33-65; Federal Geological Survey of Beograd: Beograd, Serbia, 1976.

18. Šifrer, M. Porečje Kamniške Bistrice v pleistocenu. (The basin of Kamniška Bistrica during the pleistocene period). Dela SAZU 1961, 10, 211.

19. Meze, D. Porečje Kokre v pleistocenu. Geografski Zbornik 1974, 14, 98.

20. Kuščer, D. Kvartarni savski zasipi in neotektonika. Geologija 1990, 33, 299-313. [CrossRef]

21. Šercelj, A. Pelodne Analize Pleistocenskih in Holocenskih Sedimentov Ljubljanskega Barja; Razprave 9/9, 4 Raz.; SAZU: Ljubljana, Slovenia, 1966; pp. 431-472. 
22. Pavich, M.J.; Vidic, N. Application of paleomagnetic and 10Be analyses to chronostratigraphy of Alpine glacio-fluvial terraces, Sava River Valley, Slovenia. In Climate Change in Continental Isotope Records; Swart, P., Ed.; Geophysical Monograph: Washington, DC, USA, 1993; Volume 78, pp. 263-275.

23. Vidic, N.J.; Lobnik, F. Rates of soil development of the chronosequence in the Ljubljana Basin, Slovenia. Geoderma 1997, 76, 35-64. [CrossRef]

24. Vidic, N.J. Soil-age relationships and correlations: Comparison of chronosequences in the Ljubljana Basin, Slovenia and USA. Catena 1998, 34, 113-129. [CrossRef]

25. Mihevc, A.; Bavec, M.; Häuselmann, P.; Fiebig, M. Dating of the Udin Boršt conglomerate terrace and implication for tectonic uplift in the northern part of the Ljubljana Basin (Slovenia). Acta Carsol. 2015, 44. [CrossRef]

26. Penck, A.; Brückner, E. Die Alpen in Eiszeiten; Tauchnitz: Leipzig, Germany, 1909; p. 1199. (In German)

27. Vidic, N.; Pavich, M.; Lobnik, F. Statistical analyses of soil properties on a quaternary terrace sequence in the upper Sava river valley, Slovenia, Yugoslavia. Geoderma 1991, 51, 189-211. [CrossRef]

28. Doctor, D.H.; Young, J.A. An evaluation of automated GIS tools for delineating karst sinkholes and closed depressions from 1-meter lidar-derived digital elevation data. In Proceedings of the 13th Multidisciplinary Conference on Sinkholes and the Engineering and Environmental Impacts of Karst, National Cave and Karst Research Institute, Carlsbad, New Mexico, 6-10 May 2013; pp. 449-458.

29. Obu, J.C.A.; Podobnikar, T. Algorithm for karst depression recognition using digital terrain models. Geod. Vestnik 2013, 57, 260-270. [CrossRef]

30. Šušteršič, F. The Pure Karst Model. Cave Karst Sci. 1996, 23, 25-32.

31. Triglav Čekada, M. Možnosti uporabe zračnega laserskega skeniranja (LiDAR) za geomorfološke študije. Geogr. Vestnik 2011, 83, 81-93.

32. Bondesan, A.; Meneghel, M.; Sauro, U. Morphometrical analysis of dolines. Int. J. Speleol. 1992, $21,1-55$. [CrossRef]

33. Šušteršič, F. Classic dolines of classical site. Acta Carsol. 1994, 23, 123-152.

34. Ćalić, J. Uvala-Contribution to the Study of Karst Depressions (with Selected Examples from Dinarides and Carpatho-Balkanides). Ph.D. Thesis, University of Nova Gorica, Slovenia, 2009.

35. Denizman, C. Morphometrical and spatial distribution parameters of karstic depressions, Lower Suwannee River Basin, Florida. J. Cave Karst Stud. 2003, 65, 29-35.

36. Šegina, E.; Benac, Č.; Rubinić, J.; Knez, M. Morphometrical analyses of dolines-The problem of delineation and calculation of basic parameters. Acta Carsol. 2017, in press.

37. LiDAR (Public Information of Slovenia, the Surveying and Mapping Authority of the Republic of Slovenia, LiDAR, 2015) ARSO, Ministry of the Environment. Available online: http://gis.arso.gov.si/evode/profile. aspx?id=atlas_voda_Lidar@Arso (accessed on 21 November 2017).

38. Bric, V.; Berk, S.; Oven, K.; Triglav Čekada, M. Aerofotografiranje in Aerolasersko Skeniranje Slovenije; Slovensko združenje za geodezijo in geofiziko: Ljubljana, Slovenia, 2014; Volume 20, pp. 57-71.

39. Mongus, D.; Horvat, D. Napredno orodje za obdelavo lidarskih podatkov. Geod. Vestnik 2015, 59, $153-158$.

40. Mongus, D.; Lukač, N.; Žalik, B. Ground and building extraction from LiDAR data based on differential morphological profiles and locally fitted surfaces. J. Photogramm. Remote Sens. 2014, 93, 145-156. [CrossRef]

41. Mongus, D.; Žalik, B. Computationally efficient method for the generation of a digital terrain model from Airborne LiDAR data using connected operators. IEEE J. Sel. Top. Appl. Earth Obs. Remote Sens. 2014, 7, 340-351. [CrossRef]

42. Batayneh, A.T.; Abueladas, A.A.; Moumani, K.A. Use of ground-penetrating radar for assessment of potential sinkhole conditions: An example from Ghor al Haditha area, Jordan. Environ. Geol. 2002, 41, 977-983. [CrossRef]

43. Delle Rose, M.; Leucci, G. Towards an integrated approach for characterization of sinkhole hazards in urban environments: The unstable coastal site of Casalabate, Lecce, Italy. J. Geophys. Eng. 2010, 7, 143-154. [CrossRef]

44. Gómez-Ortiz, D.; Martín-Crespo, T. Assessing the risk of subsidence of a sinkhole collapse using ground penetrating radar and electrical resistivity tomography. Eng. Geol. 2012, 149-150, 1-12. [CrossRef]

45. Rodriguez, V.; Gutiérrez, F.; Green, A.G.; Carbonel, D.; Horstmeyer, H.; Schmelzbach, C. Characterizing sagging and collapse sinkholes in a mantled karst by means of ground penetrating radar (GPR). Environ. Eng. Geosci. 2014, 20, 109-132. [CrossRef] 
46. Pueyo-Anchuela, Ó.; López Julián, P.L.; Casas-Sainz, A.M.; Liesa, C.L.; Pocoví-Juan, A.; Ramajo Cordero, J.; Perez Benedicto, J.A. Three dimensional characterization of complex mantled karst structures. Decision making and engineering solutions applied to a road overlying evaporite rocks in the Ebro Basin (Spain). Eng. Geol. 2015, 193, 158-172. [CrossRef]

47. Margiotta, S.; Negri, S.; Parise, M.; Quarta, T.A.M. Karst geosites at risk of collapse: The sinkholes at Nociglia (Apulia, SE Italy). Environ. Earth Sci. 2016, 75, 1-10. [CrossRef]

48. Zarroca, M.; Comas, X.; Gutiérrez, F.; Carbonel, D.; Linares, R.; Roqué, C.; Mozafari, M.; Guerrero, J.; Pellicer, X.M. The application of GPR and ERI in combination with exposure logging and retrodeformation analysis to characterize sinkholes and reconstruct their impact on fluvial sedimentation. Earth Surf. Process. Landf. 2016, 42, 1049-1064. [CrossRef]

49. Jol, H.M. Ground Penetrating Radar: Theory and Applications, 1st ed.; Elsevier Science: Amsterdam, The Netherlands, 2009; p. 524.

50. Shih, S.F.; Doolittle, J.A. Using radar to investigate organic soil thickness in the Florida everglades. Soil Sci. Soc. Am. J. 1984, 48, 651-656. [CrossRef]

51. Huisman, J.A.; Hubbard, S.S.; Redman, J.D.; Annan, A.P. Measuring soil water content with ground penetrating radar: A Review. Vadose Zone J. 2003, 2, 476-491. [CrossRef]

52. Lunt, I.; Hubbard, S.; Rubin, Y. Soil moisture content estimation using ground-penetrating radar reflection data. J. Hydrol. 2005, 307, 254-269. [CrossRef]

53. Simeoni, M.A.; Galloway, P.D.; O'Neil, A.J.; Gilkes, R.J. A procedure for mapping the depth to the texture contrast horizon of duplex soils in south-western Australia using ground penetrating radar, GPS and kriging. Aust. J. Soil Res. Aust. 2009, 47, 613-621. [CrossRef]

54. Breiner, J.M.; Doolittle, J.A.; Horton, R.; Graham, R.C. Performance of ground-penetrating radar on granitic regoliths with different mineral composition. Soil Sci. 2011, 176, 435-440. [CrossRef]

55. Zhang, J.; Lin, H.; Doolittle, J. Soil layering and preferential flow impacts on seasonal changes of GPR signals in two contrasting soils. Geoderma 2014, 213, 560-569. [CrossRef]

56. McNeill, J.D. Electrical Conductivity of Soils and Rock; Technical Note TN-5; Geonics Limited: Mississauga, ON, Canada, 1980; 22p.

57. Olhoeft, G.R. Electrical properties from $10^{-3}$ to $10^{+9} \mathrm{~Hz}$-Physics and chemistry. In Physics and chemistry of porous media II: Ridgefield, CT, 1986; Jayanth, R.B., Joel, K., Kenneth, W.W., Eds.; American Institute of Physics: Ridgefield, CT, USA, 1987; pp. 281-298.

58. Doolittle, J.A.; Collins, M.E. A comparison of EM induction and GPR methods in areas of karst. Geoderma 1998, 85, 83-102. [CrossRef]

59. Mala ProEx-Professional Explorer Control Unit. Operating Manual. Mala. Available online: http:/ / www.guidelinegeo.com/wp-content/uploads/2016/07/MALA-ProEx-Control-Unit-Manual-v.2.0.pdf (accessed on 23 November 2017).

60. Reynolds, J.M. An Introduction to Applied and Environmental Geophysics, 2nd ed.; Wiley: New York, NY, USA, 2011; p. 712.

61. Šušteršič, F. A conceptual model of dinaric solution doline dynamics. Cave Karst Sci. 2017, 44, 66-75.

(C) 2017 by the authors. Licensee MDPI, Basel, Switzerland. This article is an open access article distributed under the terms and conditions of the Creative Commons Attribution (CC BY) license (http:// creativecommons.org/licenses/by/4.0/). 